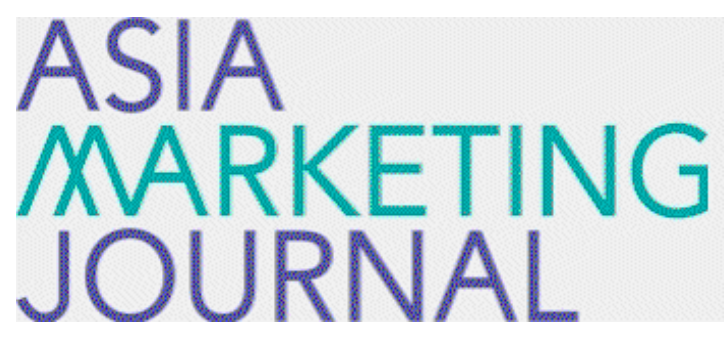

ASIA MARKETING JOURNAL

Volume 4 | Issue 4

Article 4

$12-1-2002$

\title{
한,일 양국 신세대의 소비문화에 관한 비교연구
}

Soug Shin Choi

Katakami Hiroshi

Gwang Bae Lee

Follow this and additional works at: https://amj.kma.re.kr/journal

Part of the Marketing Commons

\section{Recommended Citation}

Choi, Soug Shin; Hiroshi, Katakami; and Lee, Gwang Bae (2002) "한,일 ㅇㅑㅑ국 신세대의 소비문화에 관한 비 교연 구," Asia Marketing Journal: Vol. 4 : Iss. 4 , Article 4.

Available at: https://doi.org/10.53728/2765-6500.1097

This Article is brought to you for free and open access by Asia Marketing Journal. It has been accepted for inclusion in Asia Marketing Journal by an authorized editor of Asia Marketing Journal. 


\title{
한- 일 양국 신세대의 소비문화에 관한 비교연구
}

: 대학생들의 라이프스타일 특성 및 여가생활을 중심으로'

\section{A Comparative Study on the Consumption Cultures between the Korean and the Japanese New Generations : laying emphasis upon their lifestyle characteristics \& leisures}

\author{
최석신(전남대학교 경영대학 교수) \\ sschoi@chonnam.ac.kr, css2772@hanmail.net \\ 가타가미 히로시(일본 니가타대학교 경영학부 교수) \\ katakami@duck.ni igataum.ac.jp \\ 이광배 (순천대학교 경영통상학부 조교수) \\ kblee@sunchon.ac. $\mathrm{kr}$
}

\begin{abstract}
본 연구는 같은 동양문화권에 속하면서도 사화 문화적 배경의 다른 한국과 일본 대학생들을 대상으로 라이프스타일 특성과 여가시간 활용을 비교 분석하므로쌔 양국 대학생들의 소비문화를 추론하는데 초점을 두고 있다. 새로운 세대로 지칭되는 대학생들은 이미 새로운 수요를 창출하는 세분시장으로서 마케터들의 관심울 모으고 있지만, 국가간 시장을 세분화하고 그예 따른 적절한 마케팅 전략올 구사하는 것이 과연 효과적인가를 탐색해 보는 것이 본 연구의 목표이다.

라이프스타일은 AIO 분석에 근거하여 의생활분야, 구매 및 쇼평분야, 가치관분야, 정보추구분야, 인터넷 광고분야 등의 다섯 가지 영역으로 구분하고 양국 대학생들올 대상으로 자료를 수집하였다. 각 영역별로 요인분석올 실시하여 모두 23 개의 요인이 도출되었고, 양국 대학생 집단은 모두 18 개 부문에서 차이를 보였으며 5 개 부문에서는 유의적인 차이가 나타나지 않았다. 그러나 여가 및 시간활용에서는 양국 대학생 집단간예 차이를 보이는 항목이 많았으며, 인구 통계적 요인이 국적과 상호작용을 통해 여가활동에 서로 다르게 영향을 미치고 있는 것으로 나타났다.

이러한 연구결과는 사회- 문화적 환경이 다른 소비자 집단의 특성을 이해하고 여가활동 유형과 여가시간 활용에 따라 차별화를 가능하게 함으로써 국제적인 마케팅전략수립을 위해 효과적인 시장세분화 기준을 제공하고 소비패턴 분석을 위한 기초 자료로 활용될 수 있을 것이다.
\end{abstract}

* 논문접수 : 02.11 게재확정 : 03.02

이 논문은 2000년도 한국학술진홍재단의 지원에 의하여 연구되었음(KRF-2000-042-C00099)

익명의 심사자에 대해 사의률 표함 


\section{1. 연구의 필요성}

우리나라의 최근 인터넷 이용자는 1 천 8 백만명에 이르고 있으며 전 세계적으로는 약 2 억에 이르고 있고, 인터넷 쇼핑몰은 1999년초 400여개에서 2000년에는 약 8,000여개가 있는 것으로 추정되고 있으며 이률 이용하는 소비자도 지속적으로 중가하고 있는 추세이다. 정보통신부 자료에 따르면 국내 기업과 소비자간 전자상거래 규모는 1998년 465억원에서 2000 년에는 2,160 억원으로 성장하였으며, 2003 년에는 1 조 7,000 억원 규모로 예상하고 있다. 미국의 시장조사기관인 포레스토 리서치에 따르면 1999년 인터넷 쇼평 매출은 200 억달러(약24조원)에 이른 것으로 추산되고 있으며, 2004년에는 1,840억달러(야 222초)가 될 것으로 예측하고 있다.

컴퓨터의 보급이 확산되고 네트워크가 이루어짐으로 인해 디지털시대 환경을 자연스럽게 받아들이는 신세대는 그들의 부모인 기성세대와는 사뭇 다른 가치관과 생활방식 형태를 보이고 있다. 이들 세대는 커뮤니케이선 수단으로 디지털 매체를 사용하고, 다른 세대와 관계형성을 위한 융용한 방법으로 디지털 매체를 이용하고 있으며 물건이나 서비스률 구매하기 위한 쇼핑수단으로 인터넷을 활용하고 있다. 더욱이 인터넷의 양방향적 커뮤니캐이션에 익숙한 신세대의 문화는 일방적 커뮤니케이션 형태를 유지하던 기성세대와는 분명한 차이를 보여주고 있다. 인터넷을 통해 네트워크 게임을 하고, e-maii을 통해 시간과 공간울 초월하여 자유롭고 신속하게 의사소통을 하기도 하며, 전통적인 세대와는 다른 방식으로 자신들의 의사를 거리김 없이 교환하고 있다. 또한 인터넷을 통한 의사소통으로 커뮤니티 형성은 구전효과를 활용하는데 매우 유용할 뿐만 아니라 이러한 매체의 특성으로 인해 커뮤니케이션의 차이가 문화의 차이를 발생시키는 원천으로 이어지고 있다(Amstrong and Hagel III 1996).

이들 세대가 마케팅 관리자에게 매우 중요한 이유는 이들이 이전의 젊은 세대들보다 많은 가처분소득을 가지고 있울 뿐만 아니라, 한 가정이 구매졀정을 하는 데 보다 큰 영향력을 행사하는 매우 중요한 소비자 충으로 등장하였기 때문이다. 다지털 매체를 능숙하게 다루는 이들 세대는 인터넷울 통해 상품에 대한 비교정보를 더욱 쉽게 접할 수 있고, 오프라인에서와는 달리 온라인상에서 소비자 특성을 나타냄으로써 소비형태나 기업의 마케팅 전략에 미치게 될 영향이 그들의 부모세대와 현저히 다르게 나타나고 있다. 뿐만 아니라 이들 신새대는 몇 년 후에 경제적으로 독립하여 자립적인 소비를 할 수 있계 되기 때문에, 이러한 신세대 고객의 성향올 경쟁사보다 먼저 이해하고 이들 세대가 가지고 있는 톡성율 파악하고 분석하는 것이 매우 유용하고 바랍직할 것으로 보인다.

라이프스타일은 활동영역, 관심분야, 태도 및 가치관 등에 의해서 구체화되고 집단적으로 차별화된 생활양식이다. 라이프스타일을 통해 일상생활의 구성요소인 인간, 시간, 공간이 이루고 있는 소비문화의 제요소듈이 그대로 드러날 뿐만 아니라 이들 요소의 변화까지 포합한다. 즉 라이프스타일은 복합적 가치체계에 의해 톡징 지워지는바 이런 가치채계는 안정적이고 지속적인 속성을 지닐 뿐만 아니라 톡정한 소비대상이나 상황에 국한되지 않기 때문에 소비자의 전반적인 소비성향에 대한 예측변수로서 매우 유용성이 높다고 본다. 톡히 마케팅 분야에서 라이프스타일은 시장세분화의 기준을 제시하는 기능을 가질뿐 아니라 사희과학분야에서 인구퉁계학적 변수이외의 현상을 설명하는 또 하나의 중요한 내생 변수로서의 기능을 가질 뿐 아니라 있다. 이러한 유용성으로 인해 우리나라의 라이프스타일 
관련연구는 마케팅을 중심으로 경영학에서 뿐만 아니라 심리학, 사희학, 신문방송 및 광고계를 중심으로 활발히 이루어지고 있다. 이러한 점을 감안하여 볼 때 내트워코 환경하에서 생활하는 새로운 세대가 갖고 있는 사고방식과 행동양식을 이해하고 미래 행동을 예측하기 위해서는 소비문화의 포괄적 대체개념으로서의 라이프스타일분석을 통해 이들이 갖는 특성을 파악할 필요가 있을 것으로 판단된다.

최근 인터넷 환경을 통한 세계시장의 글로벌화의 영향으로 기업의 국제화가 더욱 활발히 진행되면서 국제마케팅 활동이 메우 중요하게 부각되고 효과적인 국제마케팅 할동어 기업의 성장과 생존에 필수요건으로 자리매김하게 되었다. 문화권에 따른 소비자의 소평행동, 가격, 민감도, 구매과정에서의 가정의 역할 등 라이프스타일에 대한 정확한 이해가 시장세분화룰 통한 국제마케팅 전략수립에 중요한 필수적 고려사항이기 때문에, 소비자의 라이프스타일에 대한 비교 문화적 연구는 매우 중요한 사항이라 할 것이다(이 철 1995).

그럽에도 불구하고 라이프스타일예 관한 비교 문화적 연구는 여러 가지 복합적인 이유로 인해 거의 이루어지지 못하고 있는 실정이다. 톡히 한국과 일본은 사회문화적 배경디 유사하면서도 가치관이나 생할양식은 상이한 특성을 가진 국가이다. 이러한 톡성을 가진 국가률 대상으로 네트워크 환경하에서의 새로운 세대에 대한 비교연구는 매우 중요함에드 불구하고 실제로 성과는 매우 빈약한 실정이다. 이러한 촉면에서 본 연구는 서로 다른 문화관의 라이프스타일이나 가치체계에 대한 정확한 이해를 통해 국제적으로 다양한 소비차 집단울 이해하고 그 특성을 퐈악할 수 있계 합으로써 시장세분화 및 마케팅전략 수립에 매우 유용한 지침이 될 수 있을 것이다.

본 연구의 목적은 다음과 같다. 먼저, 동일한 동양문화권에 속하는 한국과 일본 대학생들의 라이프스타일 핵성을 비교하여 그 차이점을 살펴본다. 라이프스타일 특성을 파악함에 있어서는 AIO 분석방법에 기초하여 신세대의 특성에 맞게 항목의 수정과 보완올 통하여 라이프스타일 뽁성 변수를 도출하고 양국 대학생들의 차이를 검토한다. 둘째, 여가활동은 소비자의 소비문화에 중대한 영향올 미치고 있음을 감안하여 양국 대학생들의 여가활동 유형과 여가시간 활용에 어떠한 차이가 있는가를 비교분석한다. 마지막으로 양국 소비자 집단은 인구 통계적 톡성에 따라 여가시간 활용에 어떠한 영향올 미치고 있는치 상호작용 여부를 분석하고, 양국의 소비자 특성에 따라 향후 마케팅 전략방안에 대해 추론해 보고자 한다.

\section{2. 연구문제}

우리나라에서는 신세대를 대상으로 라이프스타일 톡성에 관한 연구가 많지는 않으나, 각 기업에서 이들을 표적으로 하는 상품이나 서비스의 판매를 위해 이들의 소비문화와 톡성을 분석하고 있다. 이러한 분석에 따르면 우리나라의 신세대는 강한 매니아 성향은 물론 남과 다르계 보이고자 하는 욕망이 강하며, 인터넷에 둥장하는 네트워크 게임이나 비디오 게임을 선택하여 즐기며, 디지털 매체률 통해 기존의 전통적인 세대와는 완전히 다른 방식으로 자신들의 감정을 거리김 없이 표현하고 교환하고 있다. 뿐만 아니라 또래 집단과의 자유분방한 대화률 주고받는 늘이문화률 똥해 정서적 얀정과 지성적 성숙에 많은 영향을 마치고 있다고 설명하고 있다(허윤정 2000). 
탭스콧(Tapscott 1998)은 베이비붐 세대, $X$ 세대, 신세대(혹은 $N$ 세대 ${ }^{11}$ 라 칭함)률 시대별로 구분하고, 이들 신세대가 기성세대와 차이를 보이는 문화적 특징을 10 가지 (극단적 독립심, 감성적-지적 개방성, 포용성, 자유로운 표현과 강한 주장, 혁신, 성숙하기 위한 열정, 탐구심, 성급합, 기업적 이익에 대한 민감성, 사실 확인과 신뢰 둥)로 표현하고 있다. 이에 따르면 네트워크 환경하에서 생활하는 신세대는 미래에 대한 전망이나 직업관 혹온 인생관이 부모세대와 판이하게 다르며, 이데올로기를 형성하는 방법 측면에서도 부모세대와는 현격한 차이를 보인다. 또한 이들 세대는 부모와 가족듈간의 관계를 새릅게 형성할 뿐만 아니라, 네트워크률 퉁해 가족간 유대관계률 형성하는 새로운 기희률 제공해 주기도 하며 가상공간욜 통해 새로운 대화의 장이 되기도 한다.

이들 세대는 구매선택 성향도 기존 새대와는 다론 속성올 보여주고 있다. 자유로운 선택을 중시하고, 구매의사 결정율 할 매 사이버 공간에서 조직화된 정보률 빠론 시간 내에 탐색하여 의사결정을 하고 있다. 또한 이들 세대는 인터넷 매체 특성을 활용하여 제품정보를 적극적으로 탐색하고 비교쇼평이 수월해져 다양한 청보률 확보하여 제품올 선택하고 있으며, 일부는 단순한 소비자 수준올 넘어 직접적인 의사소통을 퉇해 생산과정까지 적극적으로 참여하는 생산소비자로서의 역할에 참여합으로써 그 위상이 높아지고 있다.

이와 같이 네트워크 환경하에서 신세대가 본격적인 소비자로 둥장하고, 전자상거래 시장에서 주도적인 역할을 발휘하면서 브랜드 가치의 제고, 다양한 제품정보 제공밚식, 온라인 커뮤니티 운영, 인터넷 광고운영과 방식의 변화, 광고와 관련된 윤리강령 둥이 전면적으로 재검토되고 있는 실정이다. 따라서 신세대의 중요성은 시간이 지날수록 더욱 커지고 있으며, 기업은 고객관계관리 측면에서 단순한 매출보다 고객의 생애가치(life-time value)를 고려할 경우 그 중요성은 더육 놮다진다고 할 것이다. 이러한 신세대둘의 소비형태와 구매유형을 이해하고 예측하기 위해서는 소비패턴, 지출구조, 소비성향 등을 파악하는 근거가 될 수 있는 라이프스타일 분석이 필요하며 그것이 신세대들의 소비문화를 이해하는데 유용할 것으로 판단된다.

라이프스타일 분석방법은 접근방법의 차원에 따라 거시적 접근과 미시적 접근방법으로 나눌 수 있고 분석 자료의 성격에 따라 객관적 데이터와 주관적 데이터로 분류할 수 있다. 또 측정도구의 구섬에 따라 일반적 라이프스타일(general lifestyle) 접근방법과 톡정 라이프스타일(specific lifestyle) 접근방법으로 구분하기도 한다.

거시적 챠원의 분석은 사희전체의 라이프스타일 동향을 파악하려는 목적으로 이루어지며 대표적인 분석방법은 사회경향분석법(social trend approach)이나 Stanford Research Institue(SRI)의 사회추세예측조사 등이 대표적 예이다. 그러나 거시적 차원의 분석은 사회전체의 동향만을 파악하지 개개 생활자의 특징분석은 이루어지지 않기 때문에, 라이프스타일의 새로운 동향을 잘 나타내주는 부류가 어떤 집단인지 라이프스타일의 개인차를 밝혀내기 위해서는 미시적 차원의 분석이 필요하다.

미시적 접근은 라이프스타일의 이해를 통해 사희를 세분화해 보고자 하는데 그 주요

1) 'New세대'란 미국 정보사회학지인 돋 법스못이 “Growing Up Digital: Net Generation'이라는 책에서 처올으로 명영하였으며, 주어잔 대로 받아돌이턴 TV세대와는 달리 인터넷과 갑온 디지혈 네트워크를 자유자깨로 대루는

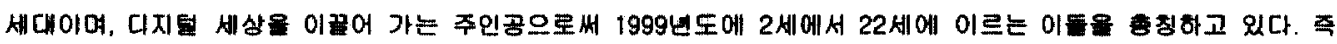

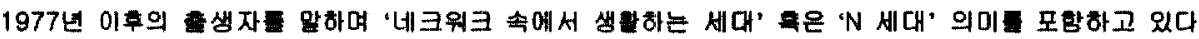


취지가 있다(채서일 1992). 즉 소비자의 가치관이나 생활습관의 패턴을 분석함으로서 사회적 경향올 파악 또는 예측하는 방법이기 때문에 특히 소비자연구에서 많이 이용되며, 미시적 분석올 이용한 대표적인 조사들로는 $\mathrm{AlO}$ 분석과 가치분석 둥이 있다.

많은 연구들이 미시적 분석방법 중에서도 AlO(Activity, Interest, Opinion) 분석방법을 선호하는바, 그 이유는 소비자행동에 있어서 집단간의 차이롤 활동, 관심, 의견이라는 세 차원과 인구통계학적 변수를 분리해야만 명확히 분석할 수 있으며, 또한 연구자의 연구의도에 따라 문항의 변형이나 수정이 가능하고, 일반적 라이프스타일 분석과 구체척 라이프스타일분석 모두에 있어 유용하게 사용될 수 있기 때문이다(정순희 2002). 오늘날의 $\mathrm{AIO}$ 분석에서는 라이프스타일과 행동과의 관계를 설명하고 소비자의 프로필을 조사하기 위해 일반적 AIO와 구체적 AIO 항목을 같이 사용되지만, 톡정제품이나 서비스의 사용과 관련된 라이프스타일은 구체적 A10에 의해 보다 면밀하게 측정할 수 있다(이학식 1999).

라이프스타일분석은 효과적인 시장세분화의 기준을 제공하고 소비자행동을 입체적으로 설명해준다는 마케팅적 의의률 가지기 때문에 표적시장에 따라 연구대상은 달라진다. 소비자행동을 연구하기 위한 라이프스타일에 대한 선행연구는 연구대상에 따라 일반적 대상과 특정대상으로 구분할 수 있거니와, 일반적. 소비자를 대상으로 한 박성연(1996)은 한국인의 라이프스타일을 의생할요인, 식생활요인; 주생활요인, 소비생활요인, 문화생활요인의 다섯 가지로 구분하여 분리하고, 군집분석과 교차분석을 봉해 한국인의 라이프스타일을 패션추구형, 생활추구형, 보수추구형 등으로 유형화하고 인구통계적인 특성 등올 파악하여 이를 종합적으로 분석하였다.

조형오(1996)는 한국인의 라이프스타일의 특징 및 라이프스타일 유형별 매체이용행위, 소비행위 등 다양한 형태적 영역에 대한 분석을 실시하여 서구지향적 자아추구형, 현실부정적 자아억제형, 미래지향적 갈등형, 전통지향적 현실순응형, 감각지향적 자유분방형, 보수적 현실향유형의 여섯 가지로 구분하고 인구통계적 톡성과 매체이용행위에 있어서의 차이률 검증하였다.

이와는 달리 특정계충을 대상으로 한 라이프스타일 연구들에는 대학생(김민정 1997; 채정숙 1999), 인터넷 사용자(김훈 1999), 여성과 주부(현소은 1998)이 있거니와 이것은 모두 특정소비자를 대상으로. 라이프스타일을 유형화한 연구들이다. 이러한 특정 대상이 중심이 된 연구라 할지라도 국가간 라이프스타일에 대한 비교 문화적 연구는 그 중요성이 점차 증가함에도 불구하고 거의 이루어지지 못하고 있는 실정이다. 채정숙(1999)은 한국과 캐나다 거주 대학생들의 라이프스타일을 비교하였던바, 라이프스타일을 의. 식, 주, 여가생핼, 구매생활, 성격유형, 가치관의 7 개영역으로 구성하고 각 영역별로 요인분석을 실시하여 비교하였으며 동서양의 문화적 가치관과 차이를 분석하였다.

본 연구는 라이프스타일 분석방법과 선행연구률 바탕으로 같은 동양문화권에 속하기 때문에 사회문화적 배경이 유사하면서도 다른 한편으로는 상당히 이질적인 요소가 많게 느껴지는 한국과 일본의 신세대들울 대상으로 라이프스타일 특성을 파악하고 여가활당 유형과 활용정도를 비교분석하여 보았다. 왜냐하면 지리적으로 가까운 한국과 일본기업들 입장에서 볼 때 양국 시장에서 서로에게 미치는 영향력이 상대적으로 높으며, 이러한 영향력으로 인해 향후 미래소비에 어떠한 영향을 미칠 것인가률 살펴보는 것은 국재시장의 세분화를 위한 기준을 제시하고 소비문화의 분석을 위해 유용한 자료로 활용될 수 있을 것이기 때문이다.

그리고 새로운 세대를 대상으로 소비문화를 분석하고 마케팅 전략을 세우려면 그들의 
생활한경내에서 연구 조사가 이루어져야 할 것이다. 그 목적올 이루기 위해 신세대들의 소비생활과 가장 밀접한 개넘은 바로 여가활동 시간이다. 신세대들이 하루를 어떻게 어디서 누구와 합께 시간을 보내는가률 살펴보는 방법이다. 우리나라의 청소년 실태조사에 의하면 신세대돌이 여가시간 중에서 가장 많온 시간을 할애하는 것은 TV시청, 컴퓨터 활용, 친구와의 만남, 영상프로그램, 레저할동 둥의 순으로 나타넜으며, 여가시간올 보내는 방법과 장소 모두 개인의 취향에 따라 다르고 여가생활을 위해 소비하는 제품 역시 개개인의 개성에 따라 다르게 나타나고 있다(허윤정 2000). 신세대들이 여가시간율 어디서, 어떻계, 무엇을 하며 보내는가에 주목하고 트랜드를 분석하는 것은 신세대률 대상으로 하는 마케팅에서 중요한 부분을 차지한다고 볼 수 있다. 이와 같은 사항을 종합적으로 규명하기 위하여 다음과 같은 연구문제를 설정하였다.

[연구문제 1] 한국과 일본 신세대 대학생들의 라이프스타일 특성에 관한 차이는 어떠한가? [연구문제 2] 한국과 일본 신세대 대학생들의 여가시간 활용에는 어떠한 차이를 보이는가?

\section{3. 연구방법}

\section{1. 조사 개요}

본 연구롤 위한 조사도구는 AIO 항목에 근거하여 선행연구돌이 작성한 설문지를 토대로 수정 보완하여 작성하였다. 설문지의 내응은 조사대상자의 인구 통계적 배경과 가정 환경적 배경올 파악하기 위한 문항 19 개와 라이프스타일 특성을 파악하기 위한 문항 90 개로 구성하였다. 라이프스타일에 관한 문항은 선행연구률 참고로 하되 신세대 대학생들의 특성을 반영할 수 있도록 인터넷과 네트와크 부분을 추가하여 구성하였다.

구체적으로 라이프스타일 특성을 구성하는 영역은 의생활 부문, 구매성향부문 둥의 생활영역과 신세대듈의 특성으로 나타날 수 있는 가치관부문, 인터넷과 같은 네트워크 한경하에서 나타날 수 있는 정보추구부문과 인터넷광고 부문올 포함하여 다섯 가지로 구성하였으며, 여가시간 활동올 비교하기 위해서는 TV시청, 컴퓨터 활용, 쇼평활동, 친구와의 만남, 영상프로그램, 스포츠활동 둥의 항목을 설정하였다.

측정도구의 타당성과 신뢰성을 높이기 위하여 한국 대학생들을 대상으로 예비조사를 거쳐서 요인분석과 Cronbach's Alpha 검중을 한 후 타당성과 신뢰성이 검중된 문항듈만을 발혜하여 본 조사에 이용하였다. 일본 자료룰 수집하기 위해 사용된 설문지는 한국에서 작성한 설문지를 일본어로 번역하여 사용하였으며, 국가간 사용되는 개념의 동질성(Mayer 1978)을 확인하기 위하여 원어민 대학원생과 일본인 교수와의 협력울 퉁해 예컨대 양국에서 상이한 개념으로 사용되는 몇 가지 표현은 설문서에서 제거하였다.

\section{2. 자료수집과 분석}

한국 자료의 수집은 전국 주요 대도시 4년제 대학교 1-2학년올 대상으로 350 여명을 
선정하여 조사를 실시하였다. 조사 시기는 2001년 5 월에 예비조사를 거쳐서 본조사는 6 월에 실시하였다. 자료 수집은 배부된 충 350 부 중 313 부가 회수되었으며 그 중 내용이 불충분한 것을 제외한 292 부가 최종분석에 사용되었다. 일본에서의 자료 수집은 동경과 오사카에 있는 4년제 대학 1-2학년을 대상으로 하였으며, 2001년 10 월에 조사를 실시하였다. 질문지는 총 350 부를 배부하여 325 부갸 회수되었거나와 그 중 내용이 불성실한 것을 제외한 305 부가 최종 분석 자료로 사용되어 총 597 개의 설문지가 분석에 이용되었다.

자료의 분석처리는 spss 10.0 을 이용하였으며, 빈도와 백분율, 요인분석, $\mathrm{t}$ 검증, $\mathrm{F}$ 검증올 적용하였다. 상호작용에 대한 검증은 Baron \& Kenny(1986)가 제시한 검증방법을 사용하였다. [그립 1]에서처럼 예측변수(경로 a), 조절변수(경로 b), 예측변수와 조절변수의 상호작용(경로 c) 등의 세 가지가 있을 경우, 상호작용의 유의성 여부는 경로 $a$ 가 유의적이고 경로 $\mathrm{c}$ 가 유의적인 경우에 지지가 된다. 예를 들어 $\mathrm{x}$ 와 $\mathrm{y}$ 간의 관계가 $\mathrm{z}$ 수준의 합수가 되면, 이때 $z$ 는 조절변수가 된다. 이는 $\mathrm{x}$ ?의 의미를 갖고 있는 상호작용 관계를 나타내며, $y$ 는 $x$ 와 $z$ 의 확률함수로 생각할 수 있다.

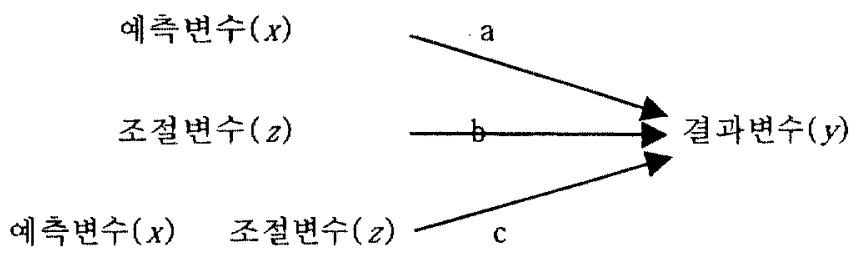

[그림 1] 상호작용 검증모형

\section{4. 연구결과 및 해석}

\section{1. 조사대상집단의 인구통계적 배경 및 가정환경적 배경}

본 연구의 조사대상이 된 한국과 일본 신세대 대학생 집단의 인구 통계적 배경올 비교하기 위하여 분석한 결과가 [표 1]에 제시되어 있다.

성별은 한국과 일본 거주 대학생 모두 남자(약 60 -66\%)가 여자(약 33 39\%)보다 더 많은 것으로 나타나 비숫한 분포를 보였으며, 연령은 전체적으로 보면 19 20세가 많고 그 다음은 18세, 21 세 순으로 나타났다. 두 집단의 연령을 비교해보면 18 20세의 분포는 한국과 일본 대학생 모두 비숫한 비율(약 85\%)로 높게 나타나 비슷한 분포률 보이고 있음옳 알 수 있다. 또한 학년별 분포에서는 전체적으로 보면 1학년(58.8\%)이 2학년(33.8\%)의 비울보다 약간 높은 것으로 나타났다. 그러나 연령 분포가 비슷한 것으로 보아 한폭 대학생의 경우 대학진학을 위한 경쟁이 반영된 것으로 판단된다. 한편 거주지역은 한국과 일본 모두 주요 대도시를 중심으로 조사를 실시하였으며, 조사대상자의 종교는 전체적으호 무교인 경우가 $50 \%$ 정도를 차지하고 있지만, 국가별로는 한국의 경우 기독교, 불교 순으포 
나타난 데 비해 일본의 경우에는 불교가 상당부문(58\%)을 차지하는 것으로 나타넜다.

[표 1] 설문 옹답자의 인구통계적 특성

\begin{tabular}{|c|c|c|c|c|c|c|c|}
\hline \multirow{2}{*}{ 변수 } & \multirow{2}{*}{ 구분 } & \multicolumn{2}{|c|}{ 한국 } & \multicolumn{2}{|c|}{ 일본 } & \multicolumn{2}{|c|}{ 계 } \\
\hline & & $\mathrm{N}$ & $\%$ & $\mathrm{~N}$ & $\%$ & $N$ & $\%$ \\
\hline \multirow{3}{*}{ 성별 } & 남 & 177 & 60.6 & 202 & 66.2 & 379 & 63.5 \\
\hline & 여 & 115 & 39.4 & 103 & 33.8 & 218 & 36.5 \\
\hline & 합계 & 292 & 100.0 & 305 & 100.0 & 597 & 100.0 \\
\hline \multirow{6}{*}{ 연령 } & 18세 & 76 & 26.0 & 37 & 12.1 & 113 & 18.9 \\
\hline & 19세 & 141 & 48.3 & 98 & 32.1 & 239 & 40.0 \\
\hline & 20세 & 56 & 19.2 & 110 & 36.1 & 166 & 27.8 \\
\hline & 21세 & 15 & 5.1 & 46 & 15.1 & 61 & 10.2 \\
\hline & 22 세 이상 & 4 & 1.4 & 14 & 4.6 & 18 & 3.0 \\
\hline & 합계 & 292 & 100.0 & 305 & 100.0 & 597 & 100.0 \\
\hline \multirow{4}{*}{ 학년 } & 대학1년 & 237 & 81.2 & 114 & 37.4 & 351 & 58.8 \\
\hline & 대학2년 & 52 & 17.8 & 150 & 49.2 & 202 & 33.8 \\
\hline & 대하ㄱㅓㅓㄴ & 3 & 1.0 & 41 & 13.4 & 44 & 7.4 \\
\hline & 합계 & 292 & 100.0 & 305 & 100.0 & 597 & 100.0 \\
\hline \multirow{5}{*}{ 거주지역 } & 서울 인천 (동경) & & & 113 & & & \\
\hline & 부산 대구 & 94 & 32.3 & 115 & 31.0 & & \\
\hline & (오사카) & 116 & 39.7 & 192 & 63.0 & & \\
\hline & 대전 광주 & 82 & 28.0 & & & & \\
\hline & 합계 & & 100.0 & 305 & 100.0 & & \\
\hline \multirow{7}{*}{ 종교 } & 불교 & 53 & 18.2 & 177 & 58.1 & 230 & 38.5 \\
\hline & 기독교 & 63 & 21.6 & 1 & 0.3 & 64 & 10.7 \\
\hline & 천주교 & 29 & 9.9 & 2 & 0.7 & 31 & 5.2 \\
\hline & 무교 & 147 & 50.3 & 104 & 34.1 & 251 & 42.0 \\
\hline & 신도 & & & 7 & 2.3 & 7 & 1.2 \\
\hline & 기타 & & & 14 & 4.6 & 14 & 2.4 \\
\hline & 합계 & 292 & 100.0 & 305 & 100.0 & 597 & 100.0 \\
\hline
\end{tabular}

다음으로 조사대상 집단의 가정 환경적 배경을 비교한 결과는 [표 2]에 제시되어 있다. 먼저 가족사항의 경우 형제여부에 관한 질문사항은 가족구성원 중 형제들을 통해 정보의 획득과 전파 및 신기술 학산에 영향을 받을 것으로 예상되었기 때문이다. 전체적으로 보면 손위형제가 없는 경우가 $44.9 \%$ 이고 동생이 없는 경우가 $53.8 \%$ 로 나타났다. 국가별로 비교해보면 한국의 경우 손위형제와 손아래 형제가 있는 경우 각각 $53.4 \%$ 와 50.3\%로 도두 $50 \%$ 이상을 나타내고 있고, 일본의 경우는 각각 $57.7 \%$ 와 $42.3 \%$ 의 비율로 나타나 큰 차이를 나타내고 있지는 않다.

부모의 연령에 대해서는 전체적으로 보면 아버지의 연령은 45 세부터 54 세까지의 비율이 75\%를 차지하고 있고, 어머니의 경우는 $73 \%$ 률 차지하는 것으로 나타났다. 국가별로 비교해보면 한국의 경우 아버지는 45-54세까지 비율이 73\%룰 차지하고 있는 반면, 일본의 경우에는 아버지의 비율이 약 $83 \%$ 를 차지하고 있었으며, 어머니의 경우에는 한국과 일본 모두 54 세 이하가 $90 \%$ 이상을 차지하고 있는 것으로 나타나 한국과 일본이 유사한 연령분포률 보여주고 있다.

부모의 직업에 대해서는 전체적으로 자영업, 영업· 기술직, 관리· 사무직이 754 률 
차지하고 있는 것으로 나타났다. 국가별로는 한국의 경우 자영업, 관리사무직, 영업기술직의 순으로 나타나고 있으며 총합은 $65 \%$ 정도룰 차지하고 있는 것으로 나타났다. 일본의 경우에

[표 2] 설문 응답자 가정 환경적 현황

\begin{tabular}{|c|c|c|c|c|c|c|c|}
\hline \multirow{2}{*}{ 변수 } & \multirow{2}{*}{ 구분 } & \multicolumn{2}{|c|}{ 한국 } & \multicolumn{2}{|c|}{ 일본 } & \multicolumn{2}{|c|}{ 계 } \\
\hline & & $N$ & $\%$ & $N$ & 8 & $\mathrm{~N}$ & b \\
\hline \multirow{6}{*}{ 가즉사함 } & 형, 누나(동생) & & & & & & \\
\hline & 0 & $139(145)$ & $47.6(49.7)$ & $129(176)$ & $42.3(57.7)$ & $268(321)$ & $44.9(53.8)$ \\
\hline & 1 & $101(122)$ & $34.6(41.8)$ & $121(95)$ & $39.7(31.1)$ & $222(217)$ & $37.1(36.3)$ \\
\hline & 2 & $36(23)$ & $12.3(7.9)$ & $51(30)$ & $16.7(9.8)$ & $87(53)$ & $14.6(8.9)$ \\
\hline & 3 & $16(2)$ & $5.5(0.7)$ & $4(4)$ & $1.3(1.3)$ & $20(6)$ & $3.4(1.0)$ \\
\hline & 합계 & $292(292)$ & 100.0 & $305(305)$ & 100.0 & $597(597)$ & 100.0 \\
\hline \multirow{7}{*}{ 부도연령 } & 아버지(어머니) & & & & & & \\
\hline & 44세 이하 & $25(95)$ & $9.2(33.6)$ & $6(45)$ & $2.1(14.8)$ & $31(140)$ & $5.5(23.9)$ \\
\hline & 45-49세 & $100(129)$ & $36.8(45.6)$ & $96(153)$ & $33.3(50.3)$ & $196(282)$ & $34.9(48.1)$ \\
\hline & 50-54세 & $99(50)$ & $36.4(17.7)$ & $131(98)$ & $45.3(32.2)$ & $230(148)$ & $41.0(25.3)$ \\
\hline & 55-59세 & $39(8)$ & $14.3(2.8)$ & $48(7)$ & $16.7(2.4)$ & $87(15)$ & $15.6(2.6)$ \\
\hline & 60 세 이상 & $9(1)$ & $3.3(0.3)$ & $7(1)$ & $2.5(0.3)$ & $16(2)$ & $3.0(0.1)$ \\
\hline & 합계 & $272(283)$ & 100.0 & $289(304)$ & 100.0 & $561(587)$ & 100.0 \\
\hline \multirow{11}{*}{ 부모쟉업 } & 야버지(어머니) & & & & & & \\
\hline & 농업 & $18(6)$ & $6.2(2.1)$ & $5(2)$ & $1.7(0.3)$ & $23(8)$ & $4.1(1.4)$ \\
\hline & 자영업 & $95(48)$ & $32.5(16.4)$ & $42(18)$ & $14.5(6.0)$ & $137(66)$ & $24.4(11.2)$ \\
\hline & 영업, 기술직 & $40(18)$ & $13.7(6.1)$ & $90(24)$ & $31.1(8.0)$ & $130(42)$ & $23.2(7.2)$ \\
\hline & 관리, 사무직 & $56(19)$ & $19.1(6.5)$ & $103(46)$ & $35.7(15.2)$ & $159(65)$ & $28.4(11.1)$ \\
\hline & 경영직 & $19(6)$ & $6.5(2.1)$ & $7(3)$ & $2.4(1.0)$ & $26(9)$ & $4.6(1.5)$ \\
\hline & 전문직 & $31(10)$ & $10.6(3.4)$ & $18(25)$ & $6.2(8.2)$ & $49(35)$ & $8.7(6.0)$ \\
\hline & 노무직 & $8(9)$ & $2.7(3.1)$ & $13(35)$ & $4.5(11.5)$ & $21(44)$ & $3.7(7.5)$ \\
\hline & 무직 & $5(7)$ & $1.7(2.4)$ & $11(0)$ & $3.9(0.0)$ & $16(7)$ & $2.9(1.2)$ \\
\hline & 주부 & $a(160)$ & $0(54.8)$ & $0(151)$ & $0(49.8)$ & $0(311)$ & $0(52.9)$ \\
\hline & 합 계 & $272(283)$ & 100.0 & $289(304)$ & 100.0 & $561(587)$ & 100.0 \\
\hline \multirow{7}{*}{$\begin{array}{c}\text { 부토교옥 } \\
\text { 수준 }\end{array}$} & 아버지(어머너) & & & & & & \\
\hline & 중졸이하 & $36(70)$ & $13.2(24.8)$ & $25(12)$ & $8.6(4.0)$ & $61(82)$ & $10.8(13.9)$ \\
\hline & 고등출 & $134(162)$ & $49.3(57.2)$ & $115(147)$ & $39.4(48.1)$ & $250(310)$ & $44.2(52.5)$ \\
\hline & 전문대졸 & $11(3)$ & $4.0(1.1)$ & $15(67)$ & $5.2(22.0)$ & $26(70)$ & $4.5(11.9)$ \\
\hline & 대학졸 & $62(46)$ & $22.8(16.3)$ & $129(77)$ & $44.1(25.3)$ & $191(123)$ & $33.8(20.8)$ \\
\hline & 대학원졸 & $29(3)$ & $10.7(1.1)$ & $8(2)$ & $2.7(0.6)$ & $37(5)$ & $6.7(0.9)$ \\
\hline & 합계 & $272(283)$ & 100.0 & $289(305)$ & 100.0 & $564(590)$ & 100.0 \\
\hline \multirow{10}{*}{$\begin{array}{l}\text { 월평균 } \\
\text { 수입 }\end{array}$} & 100 만원이 하( 10 만엔) & 15 & 5.1 & 5 & 1.6 & 20 & $\overline{3.4}$ \\
\hline & $101-150(11-15)$ & 40 & 13.7 & 21 & 6.9 & 41 & 10.2 \\
\hline & $151-200(16-20)$ & 75 & 25.7 & 25 & 8.2 & 100 & 16.8 \\
\hline & $201-250(21-25)$ & 55 & 18.8 & 20 & 6.6 & 75 & 12.6 \\
\hline & $251-300(26-30)$ & 41 & 14.0 & 29 & 9.5 & 70 & 11.7 \\
\hline & $301-350(31-35)$ & 34 & 11.6 & 41 & 13.4 & 75 & 12.6 \\
\hline & $351-400(36-40)$ & 11 & 3.8 & 40 & 13.1 & 51 & 8.5 \\
\hline & $401-500(41-50)$ & 12 & 4.1 & 42 & 13.8 & 54 & 9.0 \\
\hline & 500 만 원이상 ( 50 만윤) & 9 & 3.1 & 82 & 26.9 & 91 & 15.2 \\
\hline & 합계 & 292 & 100.0 & 305 & 100.0 & 597 & 100.0 \\
\hline
\end{tabular}




\begin{tabular}{|c|c|c|c|c|c|c|c|}
\hline \multirow{6}{*}{ 주거형태 } & 단톡주텩(자가) & 83 & 28.4 & 226 & 74.1 & 309 & 51.8 \\
\hline & 아파트, 연립(자가) & 160 & 54.8 & 46 & 15.1 & 206 & 34.5 \\
\hline & 단독주텍(전세) & 22 & 7.5 & 10 & 3.3 & 32 & 5.4 \\
\hline & 아파트, 연 립(전세) & 23 & 7.9 & 20 & 6.6 & 43 & 7.2 \\
\hline & 기타 & 4 & 1.4 & 3 & 1.0 & 7 & 1.1 \\
\hline & 합계 & 292 & 100.0 & 305 & 100.0 & 597 & 100.0 \\
\hline \multirow{5}{*}{$\begin{array}{c}\text { 부모 } \\
\text { 양역태도 }\end{array}$} & 자유밤입 & 94 & 32.2 & 168 & 55.1 & 262 & 43.9 \\
\hline & 권유주의 & 55 & 18.8 & 42 & 13.8 & 97 & 16.2 \\
\hline & 민주주의 & 132 & 45.2 & 80 & 26.2 & 212 & 35.5 \\
\hline & 기타 & 11 & 3.8 & 15 & 4.9 & 26 & 4.4 \\
\hline & 합계 & 292 & 100.0 & 305 & 100.0 & 597 & 100.0 \\
\hline
\end{tabular}

는 관리사무직이 가장 높고 영업기술직, 자영업 순으로 나타났으며 약 79\%정도를 차지하고 있는 것으로 나타났다. 어머니 직업에 대해서는 한국과 일본 모두 가사가 가장 많으나(약 $50 \%$ 정도) 직업을 갖고 있는 부분에서는 한국의 경우 자영업, 관리사무직, 영업기술직 순으로 되어있고, 일본의 경우에는 관리사무직, 자영업 순으로 나타나 비숫하게 분포되어 있음을 알 수 있다.

부모의 교욕수준은 전체적으로 고등학교 졸업이 $44 \%$ 정도이고 대학졸업은 $34 \%$ 정 드의 분포를 나타내고 있다. 이를 국가별로 비교하여 보면 한국의 경우 아버지의 학력은 고교졸, 대학졸 순으로 합계는 약 $73 \%$ 를 차지하고 있으며, 일본의 경우에는 대학졸, 고교졸업 순으로 약 $83 \%$ 의 교육수준을 보여주고 있다. 어머니의 교육수준에 대해서는 전체적으로 고교졸업이 $50 \%$ 를 상희하고 있는 것으로 나타나고 있으며, 한국의 경우에 고교졸업, 대학졸업이 57\%, $16 \%$ 를 나타내고 있고, 일본의 경우에는 $48 \%, 25 \%$ 를 나타내고 있어 어머니의 교육수른은 일본이 약간 더 높게 나타나고 있음올 알 수 있다.

월 소득에 관련되어 한국의 경우에는 151-200만원이 가장 많고 그 다음으로 201-250단원 수준으로 나타나고 있으나, 일본의 경우 100 엔올 1000 원의 환율로 환산할 경우 500 단원 이상이 가장 높은 비율을 차지하고 있어, 소득에서 일본이 횔씬 높게 나타나고 있옳을 보여주고 있다(양국의 1 인당 가처분소득의 절대비교는 경상(current)개념이기 때문에 의미가 적음). 자가의 주택형태는 전체적으로 보면 단독주택이나 아파트를 소유하고 있는 비율이 $86 \%$ 에 이르고 있는 것으로 나타났다. 이를 국가별로 비교하여 보면 한국의 경우 아파트나 단독주택을 소유한 자기소유주택이 83\%정도률 보여주고 있으며, 일본의 경우데도 자기소유 주택비율이 $83 \%$ 를 나타내고 있어 양 국가의 주거형태는 유사한 분포률 나타내고 있다.

부모의 양육태도는 한국의 경우 민주주의 형태가 가장 많고(45\%) 자유방임(32\%) 순으로 나타났으나, 일본의 경우에는 자유방임형(55\%)이 가장 높고, 민주주의형(26\%), 권위주의형 (14\%) 순으로 나타났다.

\section{2. 라이프스타일의 요인구조 특성}

양국 대학생의 라이프스타일 톡성을 비교하기 위하여 먼저 라이프스타일에 관한 문항을 각 영역별로 요인분석을 하여 그 구조를 파악하였다. 요인분석은 두 집단간 라이프스타일 특성 비교룰 용이하게 하기 위하여 한국과 일본자료를 통합하여 분석하였으며, 국가간 개념의 동질성(Mayer 1978)으로 측정하기 위해 이질적인 표현은 사전조사률 톻해 
제거하였다.

라이프스타일올 체계적으로 파악하고 신세대 톡성을 보다 효과적으로 반영하기 위하여 의생활분야, 구매 및 쇼핑분야 둥의 생활영역과 개인의 가치관을 포합하여 정보추구분야돠 인터넷광그분야 등 총 다섯 가지 영역으로 나누어 요인분석올 수행하였다. 분석방법욘 주성분분석(principal component analysis)에 의한 직각회전(varimax rotation) 방법올 이용하였으며 아이겐 값이 1.0 이상인 요인만을 추출하였고, 각 요인의 구성항목들은 적재치가 0.4 이상인 항목둘로 구성하였으며, 요인의 내적일관성을 파악하기 위하여 Cronbach's 검증을 하였다.

각 요인들의 톡성을 살펴보면, 의생활영역에서 첫 번째 요인은 패션이나 유행의 민감도와 외모에 신경을 쓰는 것 등을 나타내는 것으로서 패션지향으로 명명하였으며, 두 번째는 다른 사람과의 차별과 자신의 개성에 관련된 것으로 패션차별, 세 번째는 악세서리나 미용에 관한 것으로서 미적지향을 반영한다고 본다.

구매 및 소핑습관과 관련된 영역예서 첫 번째 요인은 주변을 의식하고 외제를 선호하는 자기과시를 반영하고 있으며, 두 번째는 제품 선택시에 꼼꼼허 살펴보고 비교 구매하논 신중한 구매를 나타내고 있다. 세 번째는 유명상표와 제조회사명을 확인하는 유명브랜드롤 구매하는 성향을 갖고 있으며, 네 번째는 세로운 상품을 선호하는 신제품선호, 다섯 번째는 인터넷을 통해 제푿을 구매하는 인터넷구쌔 유형을 나타내고 있다. 여섯 번쩨는 가격과 세일기간에 맞춘 살용구매형, 일곱 번째는 예정에 없는 물품올 구입하는 충동구매형으로 구분되는 것을 보여주고 있다.

가치관과 관련된 영역에서 첫 번째 요인은 친구 및 타인과의 대화를 추구하는 대인관계지향을 나타내며, 두 번째는 물질적인 풍요와 경제성을 나타내는 현실주의 지향을 보여주고, 세 번째는 자신의 개성과 전문성을 추구하는 개성추구지향으로 판단되며, 녜 번 째는 핸드폰 활용도가 높은 핸드폰 지향을 나타내고 있다. 다섯 번째는 인터넷에서의 팬클럽 및 동호희 활동을 선호하는 커뮤니티지향형, 여섯 번째는 새로운 변화와 개인뎌 독립성을 나타내는 개인주의 지향, 일꼽 번째 오인은 가족과의 대화 및 화합올 나타내는 가족지향을 나타내고 았다.

[표 3] 의생할염역 요인분석 결과

\begin{tabular}{|c|c|c|c|c|}
\hline 요인명 & 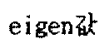 & 항목내용 & 요인적재치 & alpha \\
\hline 패션지향 & 4.494 & 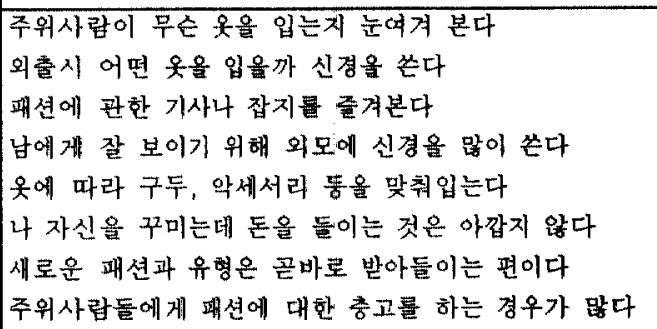 & $\begin{array}{l}.795 \\
.747 \\
.730 \\
.669 \\
.667 \\
.664 \\
.642 \\
.548\end{array}$ & .871 \\
\hline 패션차녈 & 2.397 & 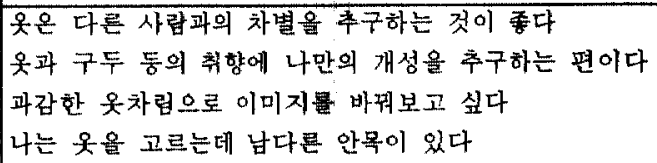 & $\begin{array}{l}.775 \\
.765 \\
.577 \\
.500\end{array}$ & 682 \\
\hline
\end{tabular}




\begin{tabular}{|c|c|c|c|c|}
\hline 미적지향 & 1.921 & $\begin{array}{l}\text { 아쁨다워질 수 있다면 성형수술은 당연하다 } \\
\text { 남자도 향수나 악세서리율 사용하는 것이 줗다 } \\
\text { 남자가 화장욯 하는 것은 자연스럼게 보인다 } \\
\text { 남자가 미장원에 가는 젓은 자연스럽다 }\end{array}$ & $\begin{array}{l}.738 \\
.695 \\
.586 \\
.572\end{array}$ & .677 \\
\hline
\end{tabular}

[표 4] 구매 쇼폄습관에 관한 요인분석 결과

\begin{tabular}{|c|c|c|c|c|}
\hline 요인명 & eigen값 & 항묙내음 & 요인젹재치 & alpha \\
\hline 자기 과시형 & 2.502 & 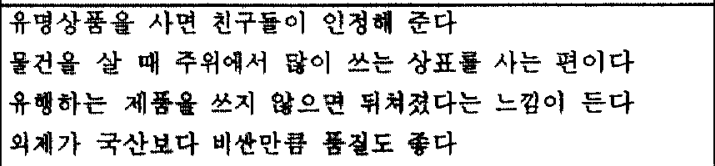 & $\begin{array}{l}.730 \\
.680 \\
.668 \\
.640\end{array}$ & .690 \\
\hline 신중구매형 & 2.404 & 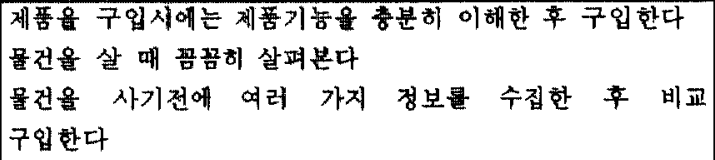 & $\begin{array}{l}.779 \\
.778 \\
.701\end{array}$ & .742 \\
\hline 유명구매형 & 2.364 & 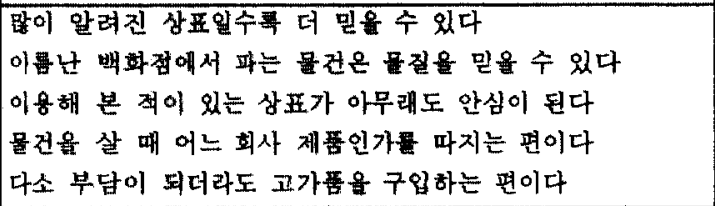 & $\begin{array}{l}.799 \\
.707 \\
.608 \\
.582 \\
.573\end{array}$ & .694 \\
\hline 신제품구태형 & 2.225 & $\begin{array}{l}\text { 새로운 상표외 욤료나 신품이 나오면 남보다 먼저 사 } \\
\text { 멱는다 } \\
\text { 신졔품이 나오면 남보다 먼저 사는 편이다 } \\
\text { 새로윤 제품은 값이 비싸더라도 사보고 싶다 }\end{array}$ & $\begin{array}{l}.790 \\
.765 \\
.664\end{array}$ & .737 \\
\hline 앤터 냇구메형 & 2.075 & 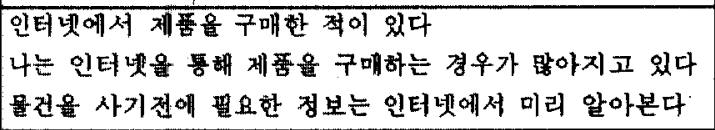 & $\begin{array}{l}.922 \\
.902 \\
.703\end{array}$ & .835 \\
\hline 실용구매형 & 2.015 & 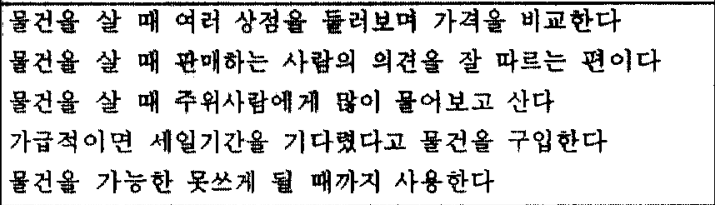 & $\begin{array}{l}.798 \\
.690 \\
.618 \\
.615 \\
.597\end{array}$ & .632 \\
\hline 충동구매형 & 1.826 & 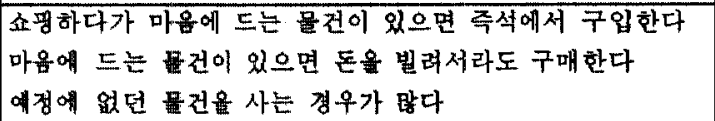 & $\begin{array}{l}.778 \\
.674 \\
.595\end{array}$ & .689 \\
\hline
\end{tabular}

[표 5] 가치관 영역 요인분석 결과

\begin{tabular}{|c|c|c|c|c|}
\hline 요인명 & eigen 값 & 항목내용 & 스인적개치 & alphis \\
\hline 대인푱계지향 & 2.598 & 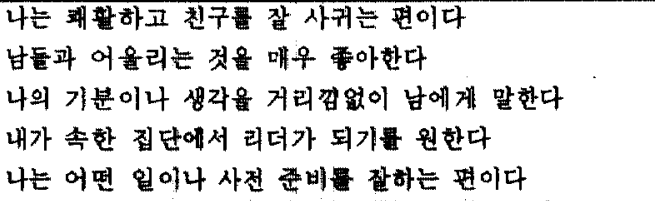 & $\begin{array}{l}.761 \\
.724 \\
.680 \\
.599 \\
.547\end{array}$ & .719 \\
\hline 현 실주외지향 & 2.198 & 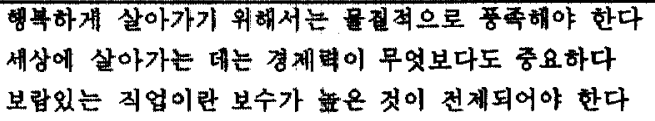 & $\begin{array}{l}.786 \\
.760 \\
.710\end{array}$ & .712 \\
\hline
\end{tabular}




\begin{tabular}{|c|c|c|c|c|}
\hline 개성추구지 향 & 2.092 & $\begin{array}{l}\text { 공부도 중요하지만 자신만의 전문분야를 갖는 것이 더 중요하다 } \\
\text { 나는 정해진 룰에 업 매이는 것을 싫어한다 } \\
\text { 돈이나 명성보다 본인의 적성에 맞는 직업선택이 더 중요하다 } \\
\text { 나는 다론 사람과는 다르게 살아보고 싶다 }\end{array}$ & $\begin{array}{l}.748 \\
.723 \\
.671 \\
.632\end{array}$ & .710 \\
\hline 혠드푼지향 & 1.957 & $\begin{array}{l}\text { 핸드폰은 펄수품이다 } \\
\text { 핸드폰 기능 중 문자서비스를 하루에 두 번 이상 이용한다 } \\
\text { 핸드폰을 봉헤 인터넷에 접속하는 것이 현대인의 펼수이다 }\end{array}$ & $\begin{array}{l}.774 \\
.648 \\
.593\end{array}$ & .644 \\
\hline 커뮤내터쟈향 & 1.866 & $\begin{array}{l}\text { 나는 인터넷애서 동호회 홥통에 적극 참여한다 } \\
\text { 나는 중아하는 연 에인의 탤를 럽에 가입해 있다 } \\
\text { 인터넷에서는 나만의 공간울 확보할 수 있다 }\end{array}$ & $\begin{array}{l}.739 \\
.716 \\
.667\end{array}$ & .705 \\
\hline 개인주의쟈향 & 1.725 & $\begin{array}{l}\text { 신세대는 항상 새뵴게 변화할 수 있어야 한다 } \\
\text { 신세대는 개성이 중시되어야 한다고 생각한다 } \\
\text { 친구들과 식사나 군것질할 때 각작 나누어 내는 것이 편하다 } \\
\text { 내 삶에 다른 사합이 끼어드는 것은 볼편하다 }\end{array}$ & $\begin{array}{l}.681 \\
.647 \\
.578 \\
.556\end{array}$ & .658 \\
\hline 가족지향 & 1.723 & $\begin{array}{l}\text { 가족과의 대화시간이 많온 편이다 } \\
\text { 납자도 가사와 소평을 도와주어야 한다 } \\
\text { 집안일을 잘 도우는 편이다 }\end{array}$ & $\begin{array}{l}.704 \\
.695 \\
.621\end{array}$ & .668 \\
\hline
\end{tabular}

정보영역과 관련된 부분에서 첫 번째 요인은 신속한 정보수집과 관련된 정보우선지향과 관련되며, 두 번째는 인터넷을 통한 정보효과지향을 나타내고, 세 번째는 가수나 연에인의 정보를 보여주는 연예정보지향올 나타내고 있다. 다음으로 인터넷 광고영역과 관련된 부분에서 첫 번째 요인은 인터넷을 통한 광고를 선호하는 인터넷 광고선호를 나타내며, 두 번째는 인터넷을 통헤 개별적인 광고서비스 및 의사소통올 나타내는 인터넷광고 개인주의를 나타내고, 세 번째 요인은 인터넷광고 신뢰형을 나타내고 있다.

한편 Nunnally(1978)에 의하면 Cronbach's alpha 계수가 0.60 0.80 일 때 신뢰도가 유지된다고 보거니와 이러한 관점에서 본 연구의 신뢰도는 대체적으로 양호한 편으로 보인다.

[표 6] 정보영역 요인분석 결과

\begin{tabular}{|c|c|c|c|c|}
\hline 8인명 & eigen값 & 항목내용 & 요인적재치 & Alpha \\
\hline 정보우선지 향 & 3.315 & 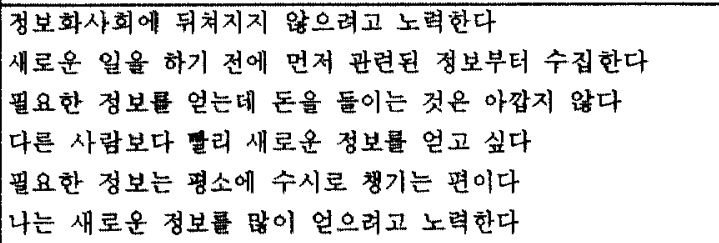 & $\begin{array}{l}.839 \\
.780 \\
.775 \\
.763 \\
.762 \\
.681\end{array}$ & .877 \\
\hline 정보효과지향 & 2.308 & 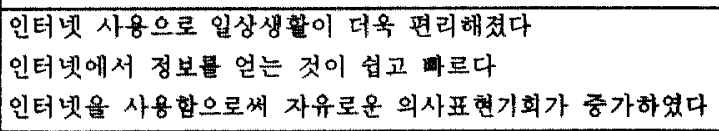 & $\begin{array}{l}.904 \\
.833 \\
.776\end{array}$ & .841 \\
\hline 연 예정보지향 & 2.043 & $\begin{array}{l}\text { 가수나 탤런트 등 연예인에 대한 소식을 많이 아는 편이다 } \\
\text { 나는 새로운 화재거리로 대화를 주도해 나가는 편이다 }\end{array}$ & .816 & .751 \\
\hline
\end{tabular}


[표 7] 광고영역에 관한 요인분석

\begin{tabular}{|c|c|c|c|c|}
\hline 요인명 & eigen값 & 항목내용 & 요인격재치 & alpha \\
\hline $\begin{array}{c}\text { 인터넷광고 } \\
\text { 선호형 }\end{array}$ & 3.023 & 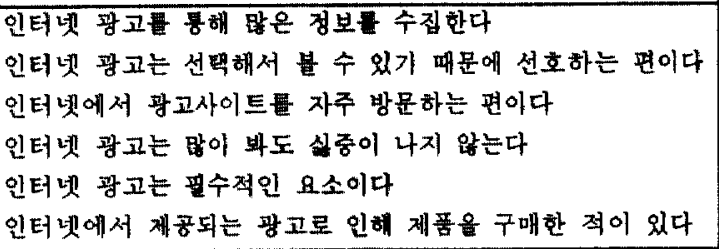 & $\begin{array}{l}.782 \\
.773 \\
.723 \\
.662 \\
.638 \\
.566\end{array}$ & .810 \\
\hline $\begin{array}{l}\text { 인터넷광고 } \\
\text { 개인주의형 }\end{array}$ & 1.952 & $\begin{array}{l}\text { 나는 자주 접속하는 푹정 사이트가 있다 } \\
\text { 나는 E-mail 서비스광고를 받아보고 있다 } \\
\text { E-mail을 풍해 친구들과 자주 의사소풍율 하는 편이다 }\end{array}$ & $\begin{array}{l}.771 \\
.684 \\
.672 \\
\end{array}$ & .714 \\
\hline $\begin{array}{c}\text { 인터넷광고 } \\
\text { 신뢰형 }\end{array}$ & 1.871 & 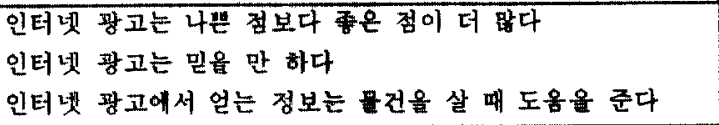 & $\begin{array}{l}.819 \\
.759 \\
.630\end{array}$ & 688 \\
\hline
\end{tabular}

\section{3. 양국 대학생의 라이프스타일 특성비교}

이상에서 분류된 라이프스타일 특성이 한국과 일본 대학생 집단간에 차이가 있는지를 비교하기 위해서 각 영역별 라이프스타일 요인에 해당되는 항목들의 평균점수롤 내더 $\mathrm{t}$ 검중을 실시한 결과가 [표 8]에 제시되어 있다.

[표 8] 한국과 일본 대학생의 라이프 스타일 요인 비교 분석

\begin{tabular}{|c|c|c|c|c|c|c|c|c|}
\hline \multirow{2}{*}{ 범주 } & \multirow{2}{*}{ 그룹 구분 } & \multicolumn{2}{|c|}{ 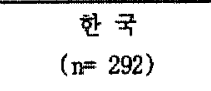 } & \multicolumn{2}{|c|}{$\begin{array}{c}\text { 일 본 } \\
(\mathrm{n}=305)\end{array}$} & \multicolumn{2}{|c|}{ 합 계 } & \multirow[t]{2}{*}{$\begin{array}{c}t \text { 값 } \\
\text { (유의수준) }\end{array}$} \\
\hline & & 평균 & $\begin{array}{l}\text { 표준 } \\
\text { 편차 }\end{array}$ & 평균 & $\begin{array}{l}\text { 표준 } \\
\text { 편차 }\end{array}$ & 평균 & $\begin{array}{l}\text { 표준 } \\
\text { 편차 }\end{array}$ & \\
\hline \multirow{3}{*}{$\begin{array}{l}\text { 의생활 } \\
\text { 추구성향 }\end{array}$} & 패션지향 & 3.11 & .69 & 2.97 & .87 & 3.04 & .79 & $2.185(.029)$ \\
\hline & 패션차녈 & 3.12 & .75 & 2.76 & .73 & 2.93 & .76 & $5.969(.000)$ \\
\hline & 미적지향 & 2.80 & .65 & 2.44 & .72 & 2.62 & .71 & $6.496(.000)$ \\
\hline \multirow{7}{*}{$\begin{array}{l}\text { 구매 딫 } \\
\text { 쇼평한동 }\end{array}$} & 과시구매 & 2.77 & .65 & 2.20 & .66 & 2.47 & .72 & $10.520(.000)$ \\
\hline & 신중구매 & 3.35 & .71 & 3.42 & .92 & 3,39 & .82 & $-1.119(.264)$ \\
\hline & 유명구메 & 3.18 & .64 & 3.36 & .73 & 3.27 & .69 & $-3.111(.002)$ \\
\hline & 신품구매 & 2.52 & .78 & 2.40 & .91 & 2.46 & .85 & $1.762(.079)$ \\
\hline & 인터넷구며 & 2.17 & 1.04 & 1.87 & .96 & 2.02 & 1.01 & $3.621(.000)$ \\
\hline & 실용구매 & 3.37 & .55 & 3.25 & .67 & 3.31 & .62 & $2.397(.017)$ \\
\hline & 훙동구미 & 2.77 & .88 & 2.80 & .86 & 2.79 & .87 & $-0.360(.719)$ \\
\hline \multirow{7}{*}{ 가치관 } & 퐌계지항 & 3.37 & .68 & 2.92 & .75 & 3.14 & .75 & $7.706(.000)$ \\
\hline & 현실경제 & 3.91 & .67 & 3.51 & .76 & 3.70 & .74 & $6.652(.000)$ \\
\hline & 개성추구 & 4.14 & .61 & 3.80 & .66 & 3.97 & .66 & $6.391(.000)$ \\
\hline & 잰드폰할용 & 3.60 & .76 & 3.70 & .90 & 3.65 & .83 & $-1.390(.165)$ \\
\hline & 커뮤니티 & 2.39 & .86 & 1.66 & .73 & 2.02 & .88 & $11.097(.000)$ \\
\hline & 개인주의 & 3.63 & .61 & 3.38 & .69 & 3.50 & .66 & $4.618(.000)$ \\
\hline & 가족지 형 & 3.48 & .71 & 3.40 & .80 & 3.44 & .76 & $1.296(.196)$ \\
\hline \multirow{3}{*}{ 졍보활동 } & 정보추구 & 3.43 & .65 & 2.90 & .76 & 3.16 & .75 & $9.097(.000)$ \\
\hline & 겅보효과 & 4.05 & .71 & 3.30 & 1.04 & 3.67 & .96 & $10.097(.000)$ \\
\hline & 연예가정보 & 2.82 & .78 & 2.64 & .94 & 2.73 & .87 & $2.564(.011)$ \\
\hline
\end{tabular}




\begin{tabular}{|c|c|c|c|c|c|c|c|c|}
\hline \multirow{3}{*}{ 광고 } & 광고선호 & 2.23 & .70 & 1.93 & .72 & 2.08 & .73 & $5.097(.000)$ \\
\cline { 2 - 9 } & 광고개인화 & 3.82 & .74 & 2.65 & 1.06 & 3.22 & 1.09 & $15.461(.000)$ \\
\cline { 2 - 9 } & 광고신최 & 2.73 & .69 & 2.42 & .76 & 2.57 & .74 & $5.217(.000)$ \\
\hline
\end{tabular}

한국과 일본 신세대들의 라이프스타일 특성을 살펴보면 의생활 부문에서는: 패션지향 $(\mathrm{t}=2.18)$ 과 패션차별 $(\mathrm{t}=5.96)$ 그리고 미적지향 $(\mathrm{t}=6.49)$ 에서 한국 대학생이 일본보다 평균값이 모두 높게 나타났으며, 두 집단간의 평균차이를 점증한 결과 통계적으로 유의적인 차이를 보여주고 있다.

구매 및 쇼핑습관부문에 대해서는 한국 대학생이 일본 대학생에 비해 과시구매성향이 가장 큰 차이를 보이는 것으로 나타났으며 $(\mathrm{t}=10.52)$, 인터넷구매 $(\mathrm{t}=3.62)$ 와 실용구매 $(t=2.39)$ 또한 한국 대학생이 일본에 비해 더 높고 유의적인 챠이를 보여주고 있다. 그러나 유명브랜드나 유명기업을 선호하는 유명구매에서 한국보다 일본 대학생의 선호도가 더 높은 것으로 나타난 점은 유의해야할 것으로 판단된다 $(\mathrm{t}=-3.11)$. 그러나 신제품구매 및 충동구매에서는 양국 집단간에 유의적인 차이가 없지만, 신중구매는 부호가 (-)로 나타나 일본 대학생이 좀더 신중한 제품선택성향을 보이고 있는 것으로 판단된다.

한편 가치관부문에 대해서는 한국의 대학생이 관계 지향적인 측면 $(t=7.70)$ 과 현실경제지항 $(\mathrm{t}=6.65)$ 및 개성추구 $(\mathrm{t}=6.39)$, 커뮤니티 지향 $(\mathrm{t}=11.09)$, 개인주의 성향 $(\mathrm{t}=4.61)$ 에 있어서 일본 대학생들보다 평균이 높고 통계적으로도 유의적인 차이룰 보여주고 얐다. 그러나 핸드폰할용과 가족지향측면에서는 한국과 일본 대학생 모두 유의적인 차이를 보이고 있지는 않으나 핸드폰 지향성향은 부호가 (-)를 나타내고 있다.

정보활동에서는 한국 대학생이 일본 대학생들에 비해 정보추구성향 $(\mathrm{t}=9.09)$ 과 정보효과 추구 $(\mathrm{t}=10.09)$ 및 연예가 정보지향 $(\mathrm{t}=2.56)$ 에 보다 높은 관심울 나타내고 있으며, 통계적으로 유의적인 수준을 보여주고 있다. 마지막으로 인터넷광고와 관련해서는 한국 대학생이 일본의 경우에 비해 인터넷을 통한 개인화된 광고를 더 자주 접하고 $(\mathrm{t}=15.46)$, 인터넷 광고 $(\mathrm{t}=5.09)$ 를 선호하며, 인터넷 광고에 대한 산뢰성 $(\mathrm{t}=5.21)$ 도 높게 나타넜다.

\section{4. 한국과 일본 대학생의 여가활동 비교분석}

한국과 일본 대학생들의 여가활동을 비교 분석하였다. 여가활동은 대표적인 유형에 따라 친구와의 만남, 쇼핑, 인터넷 PC활용, 오락실, 카페, 당구장, TV 및 비디오, 영화관람, 스포츠, 봉사활동, 종교활동 등 홓 11 개 활동으로 구분하여 조사하였다. 조사결과는 [표 9]에 제시된 바와 같으며, 제시된 숫자는 일주일간 여가활동에 대한 활동시간올 평균치로 환산한 값이다.

[표 9] 한국과 일본 여가활동 비교분석

\begin{tabular}{|c|c|c|c|c|c|c|c|c|c|c|c|c|c|}
\hline \multirow{3}{*}{ 구분(한국) } & \multicolumn{2}{|c|}{$\begin{array}{c}\text { 전체 평균 } \\
\text { (분) }\end{array}$} & \multicolumn{2}{|c|}{$\begin{array}{l}\text { 표준편차 } \\
\text { (분) }\end{array}$} & \multicolumn{4}{|c|}{$\begin{array}{c}\text { 여가한둥자 } \\
\text { (명) }\end{array}$} & \multicolumn{2}{|c|}{$\begin{array}{l}\text { 여가할동자 } \\
\text { 평균(분) }\end{array}$} & \multicolumn{2}{|c|}{$\begin{array}{l}\text { 여가합동자 } \\
\text { 표준편차(분) }\end{array}$} & \multirow[t]{3}{*}{$\begin{array}{c}t \text { 값 } \\
\text { (유의수준) }\end{array}$} \\
\hline & \multirow[b]{2}{*}{ 한국 } & \multirow[b]{2}{*}{ 일본 } & \multirow[b]{2}{*}{ 한국 } & \multirow[b]{2}{*}{ 일본 } & \multicolumn{2}{|c|}{ 한국 } & \multicolumn{2}{|c|}{ 일본 } & \multirow[b]{2}{*}{ 한국 } & \multirow[b]{2}{*}{ 일본 } & \multirow[b]{2}{*}{ 한국 } & \multirow[b]{2}{*}{ 일본 } & \\
\hline & & & & & 명 & $\begin{array}{l}\text { 비율 } \\
\text { (\$) }\end{array}$ & 명 & $\begin{array}{l}\text { 베율 } \\
\text { (4) }\end{array}$ & & & & & \\
\hline 친구와 만남 & 969 & 727 & 983 & 769 & 256 & 87 & 252 & 82 & 1105 & 880 & 975 & 763 & $3.351(.001)$ \\
\hline 쇼푱 & 122 & 259 & 223 & 316 & 113 & 38 & 222 & 72 & 315 & 356 & 261 & 320 & $-6.110(.000)$ \\
\hline
\end{tabular}




\begin{tabular}{|c|c|c|c|c|c|c|c|c|c|c|c|c|c|}
\hline 인터넷 & 618 & 129 & 694 & 270 & 232 & 79 & 109 & 35 & 777 & 363 & 694 & 347 & $11.410(.000)$ \\
\hline 오락실 & 67 & 26 & 133 & 160 & 88 & 30 & 26 & 8 & 223 & 310 & 156 & 468 & $3.382(.001)$ \\
\hline 가배 & 82 & 46 & 203 & 140 & 67 & 23 & 54 & 17 & 359 & 261 & 284 & 237 & $2.536(.011)$ \\
\hline 당구장 & 74 & 29 & 164 & 140 & 66 & 23 & 31 & 10 & 328 & 291 & 189 & 346 & $3.581(.000)$ \\
\hline TV 및 비디오 & 494 & 593 & 535 & 583 & 214 & 73 & 225 & 73 & 675 & 805 & 518 & 540 & $-2.160(.031)$ \\
\hline 영화관 & 71 & 42 & 158 & 144 & 86 & 29 & 47 & 15 & 242 & 273 & 209 & 270 & $2.363(.018)$ \\
\hline 스포츠 & 159 & 215 & 252 & 372 & 126 & 43 & 124 & 40 & 369 & 530 & 265 & 418 & $-2.153(.032)$ \\
\hline 봉사활둥 & 6 & 8 & 38 & 83 & 9 & 3 & 4 & 1 & 194 & 622 & 115 & 437 & $-0.406(.685)$ \\
\hline 종교환동 & 51 & 19 & 203 & 235 & 41 & 14 & 7 & 2 & 364 & 860 & 427 & 1405 & $1.744(.032)$ \\
\hline
\end{tabular}

[표 9]에 제시된 바와 같이 한국과 일본 대학생들의 여가활동은 봉사활동과 종교활둥올 제외한 모든 부분에서 유의적인 차이가 있는 것으로 나타났다. 구체적으로 살펴보면 한국과 일본 대학생들의 가장 큰 여가생활의 차이는 인터넷 $\mathrm{PC}$ 활용과 쇼평활동에서 두드러지게 나타나고 있음올 알 수 있다. 즉 한국 대학생들은 매일 평균 1시간 반정도 인터넷 및 $\mathrm{PC}$ 활용을 하고 있는 것으로 나타나 일본 대학생들보다 활용도가 높계 나타나고 있다 $(\mathrm{t}=11.410, \mathrm{p}=0.000)$. 그러나 쇼핑과 관련해서는 오히려 일본 대학생들의 관심과 여가활용도가 높게 나타나고 있다 $(\mathrm{t}=-6.110, \mathrm{p}=0.000)$. 이러한 결과는 일본 대학생둘이 브랜드 구매를 선호하는 속성과 구매 및 쇼핑활동에 매우 신중하게 제품울 선택하는 경향이 있는 것으로 판단된다.

그리고 한국 대학생들은 당구장 $(\mathrm{t}=3.581, \mathrm{p}=0.000)$, 오락실 $(\mathrm{t}=3.382, \mathrm{p}=0.001)$, 친구와 만남 $(\mathrm{t}=3.351, \mathrm{p}=0.001)$, 카페에서 보내는 시간 $(\mathrm{t}=2.536, \mathrm{p}=0.011)$, 영화관람 $(\mathrm{t}=2.363$, $\mathrm{p}=0.018$ ) 둥에 더 많은 여가률 활용하고 있는 것으로 나타난 반면, 일본 대학생들은 TV 및 비디오 시청 $(\mathrm{t}=-2.160, \mathrm{p}=0.031)$, 스포츠 활동 $(\mathrm{t}=-2.153, \mathrm{p}=0.032)$ 에 더 많은 시간을 할애하고 있는 것으로 나타났다. 이러한 결과로 볼 때 한국 대학생들의 경우 여가할용 유형은 당구장, 친구와 만남 등 주변 동료들과 함께 보내는 시간활용이 많고, 일본 대학생들은 집에서의 TV 및 비디오 시청과 스포츠 활동 등으로써 커뮤니티를 톻한 여가활용보다는 개인주의적 활동성향이 더 높음을 알 수 있다.

\section{5. 한국과 일본 신세대 대학생들의 성별 여가활동 비교분석}

대학생들의 국적과 성별에 따라 여가활용 정도에 어떻게 차어가 있는가를 살펴보기 어해 분산분석울 통해 상호작용을 검중하였다. 이때 검중방법은 국적이나 성별이 유의적이고, 상호작용함이 유의적인 결과로 나타나면 국적과 성별이 상호작용하여 여가활동에 다르게 영향을 미치고 있음을 나타낸다고 할 수 있다. 여가활동 비교분석올 위한 항목은 국가별 차이가 유의적인 항목만으로 한정하였다. 분석결과는 [표 10]에 제시된 바와 같으며 통계적으로 유의적인 항은 굵은 글자체로 나타내었다.

먼저, 성별에 따른 여가활동을 분석해보면 양국의 여학생들은 쇼핑활동 $(\mathrm{F}=32.436$, $\mathrm{p}=0.000)$ 과 카페에서의 시간활용 $(\mathrm{F}=18.430, \mathrm{p}=0.000)$ 및 영화관람 $(\mathrm{F}=5.146, \mathrm{p}=0.024)$ 에 많은 시간을 보내고 있는 것으로 나타넜으며, 남학생들은 스포츠 할동 $(\mathrm{F}=29.554, \mathrm{p}=0.000)$, 당구장 $(\mathrm{F}=20.055, \mathrm{p}=0.000)$, 오락실 $(\mathrm{F}=6.424, \mathrm{p}=0.012)$ 순으로 여가시간을 할용하고 있는 것으로 나타났다. 그러나 친구와의 만납과 인터넷 활용시간, TV 및 비디오 관람을 톻한 
여가시간 활용부문에서는 성별에 따라 유의적인 차이를 나타내고 있지 않다.

다음으로 국가와 성별에 따른 상호작용올 통해서 여가 활동에 어떠한 차이를 보이고 있는가를 살펴보았다. 상호작용이 발생하는 활동영역은 친구와 만남, 인터넷 및 $\mathrm{PC}$ 활용, 카패이용시간, 당구장 시간활용 등으로 나타났다. 즉, 친구와의 만남과 인터넷 PC활용은 국가별로 유의적인 차이 $(\mathrm{F}=7.524, \mathrm{p}=0.006 ; \mathrm{F}=110.426, \quad \mathrm{p}=0.000)$ 률 보이고 있고 상호작용항 $(\mathrm{F}=4.748, \mathrm{p}=0.030 ; \mathrm{F}=4.587, \mathrm{p}=0.033)$ 이 유의적인 것으로 나타났다. 이를 구체적으로 살펴보면 친구와의 만남을 통한 시간활용은 [표 10]에 나타난 바와 같이 한국과 일본 남학생의 경우 평균 2.5 시간과 2.1 시간 정도로 한국 남학생의 시간활용이 높은 것으로 나타넜으며, 여학생의 경우는 1.9 시간 정도로 양국 모두 유샤한 시간을 할용하고 있는 것으로 나타났으나 상대적으로 비교하여 볼 때 한국의 남학생과 일본의 여학생이 더 많은 시간을 할애하고 있옴울 알 수 있다. 또한 인터넷. $\mathrm{PC}$ 할용을 통한 여가활동은 한국 대학생들의 시간활용이 일본보다 매우 높은 것으로 나타나고 있다. 성별로 구분하여 보면 한국과 일본 남학생의 경우 인터넷 PC활용시간은 평균 1.6 시간과 0.3 시간으로 한국 남학생의 시간활융이 매우 높게 나타나고 있으며, 여학생의 경우는 1.3시간과 0.4 시간으로 역시 한국 여학생의 시간활용이 높개 나타나고 있다. 그러나 상대적으로 비교하여 볼 때 한국의 남학생과 일본의 여학생이 더 많은 시간을 활용하고 있음을 알 수 있다.

국가와 성별에 따른 상호작용은 카페이용과 당구장에서 시간활용 등의 여가활동에 다르게 영향을 미치고 있음올 보여주고 있다. 카페에서의 여가시간 활용도는 국가와 성별이 유의적 $(\mathrm{F}=7.903, \mathrm{p}=0.005 ; \mathrm{F}=18.430, \mathrm{p}=0.000)$ 임과 동시에 상호작용항도 유의적 $(\mathrm{F}=4.522$, $\mathrm{p}=0.034$ )으로 나타나고 있다. 즉 한국과 일본 여학생의 경우 카페이용 평균 시간활용은 0.3 시간과 0.15 시간으로 한국 여학생의 시간활용이 약 두 배 정도로 높게 나타넜다. 남학생의 경우는 양국 모두 0.1 시간으로 유사하게 시간을 할애하고 있으나, 국가간 상대적으로 비교하여 보면 한국의 여학생과 일본의 남학생이 더 많은 시간을 할애하고 있다.

[표 10] 한국과 일본 성별 여가생활 비교분석

\begin{tabular}{|c|c|c|c|c|c|c|c|c|c|c|c|c|c|c|c|}
\hline \multirow{3}{*}{ 구 분 } & \multicolumn{4}{|c|}{$\begin{array}{c}\text { 한 국 } \\
(n=292)\end{array}$} & \multicolumn{4}{|c|}{$\begin{array}{c}\text { 일 본 } \\
(n=305)\end{array}$} & \multicolumn{4}{|c|}{$\begin{array}{c}\text { 함 계 } \\
(n=597)\end{array}$} & \multirow{2}{*}{\multicolumn{3}{|c|}{$\begin{array}{c}\mathrm{F} \text { 값 } \\
\text { (유의수준) }\end{array}$}} \\
\hline & \multicolumn{2}{|c|}{$\begin{array}{c}\text { 将 } \\
(n=177)\end{array}$} & \multicolumn{2}{|c|}{$\begin{array}{c}\text { 여 } \\
(n=115)\end{array}$} & \multicolumn{2}{|c|}{$\begin{array}{c}\text { 남 } \\
(n=202)\end{array}$} & \multicolumn{2}{|c|}{$\begin{array}{c}\text { क्व } \\
(n=103)\end{array}$} & \multicolumn{2}{|c|}{ 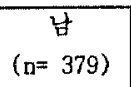 } & \multicolumn{2}{|c|}{$\begin{array}{c}\text { 여 } \\
(\mathrm{n}=218)\end{array}$} & & & \\
\hline & 평균 & $\begin{array}{l}\text { 표준 } \\
\text { 편차 }\end{array}$ & $\begin{array}{l}\text { 평 } \\
\text { 균 }\end{array}$ & $\begin{array}{l}\text { 표준 } \\
\text { 편차 }\end{array}$ & $\begin{array}{l}\text { 평 } \\
\text { 균 }\end{array}$ & $\begin{array}{l}\text { 표준 } \\
\text { 편차 }\end{array}$ & $\begin{array}{l}\text { 평 } \\
\text { 간 }\end{array}$ & $\begin{array}{l}\text { 표준 } \\
\text { 편차 }\end{array}$ & $\begin{array}{l}\text { 평 } \\
\text { 균 }\end{array}$ & $\begin{array}{l}\text { 표준 } \\
\text { 편차 }\end{array}$ & $\begin{array}{l}\text { 평 } \\
\text { 균 }\end{array}$ & $\begin{array}{l}\text { 표준 } \\
\text { 편차 }\end{array}$ & 국적 & 성별 & $\begin{array}{c}\text { 국적*성 } \\
\text { 별 }\end{array}$ \\
\hline $\begin{array}{l}\text { 친구와 } \\
\text { 만남 }\end{array}$ & 1081 & 1088 & 797 & 768 & 713 & 804 & 755 & 700 & 885 & 963 & 777 & 735 & $\begin{array}{r}7.524 \\
(.006)\end{array}$ & $\begin{array}{r}2.617 \\
(.106) \\
\end{array}$ & $\begin{array}{r}4.748 \\
(.030) \\
\end{array}$ \\
\hline 쇼푱 & 59 & 165 & 218 & 264 & 225 & 310 & 326 & 318 & 147 & 266 & 269 & 295 & $\begin{array}{l}36.197 \\
(.000)\end{array}$ & $\begin{array}{l}32.436 \\
(.000)\end{array}$ & $\begin{array}{r}1.551 \\
(.213)\end{array}$ \\
\hline 인터넷 & 678 & 761 & 525 & 565 & 117 & 223 & 154 & 345 & 379 & 612 & 350 & 508 & $\begin{array}{r}110.426 \\
(.000)\end{array}$ & \begin{tabular}{|l|}
1.689 \\
$(.194)$
\end{tabular} & $\begin{array}{r}4.587 \\
(.033)\end{array}$ \\
\hline 오락실 & 79 & 150 & 49 & 101 & 37 & 194 & 4 & 32 & 57 & 176 & 27 & 80 & $\begin{array}{l}11.831 \\
(.001)\end{array}$ & $\begin{array}{r}6.424 \\
(.012) \\
\end{array}$ & $\begin{array}{l}0.015 \\
(.901)\end{array}$ \\
\hline 카페 & 45 & 141 & 139 & 262 & 35 & 123 & 67 & 168 & 40 & 132 & 105 & 225 & $\begin{array}{l}7.903 \\
(.005)\end{array}$ & $\begin{array}{l}18.430 \\
(.000)\end{array}$ & $\begin{array}{r}4.522 \\
(.034)\end{array}$ \\
\hline 당구장 & 114 & 196 & 12 & 55 & 33 & 115 & 22 & 179 & 71 & 163 & 17 & 129 & $\begin{array}{l}7.939 \\
(.005)\end{array}$ & $\begin{array}{l}20.055 \\
(.000)\end{array}$ & $\begin{array}{l}12.951 \\
(.000)\end{array}$ \\
\hline
\end{tabular}




\begin{tabular}{|c|c|c|c|c|c|c|c|c|c|c|c|c|r|r|r|}
\hline $\begin{array}{r}\text { TV 및 } \\
\text { 비다오 }\end{array}$ & 474 & 518 & 526 & 560 & 585 & 582 & 610 & 590 & 533 & 555 & 565 & 574 & $\begin{array}{r}4.157 \\
(.042)\end{array}$ & $\begin{array}{r}0.640 \\
(.424)\end{array}$ & $\begin{array}{r}0.085 \\
(.771)\end{array}$ \\
\hline 영화판 & 59 & 153 & 89 & 165 & 32 & 135 & 61 & 159 & 45 & 144 & 76 & 162 & $\begin{array}{r}4.640 \\
(.032)\end{array}$ & $\begin{array}{r}5.146 \\
(.024)\end{array}$ & $\begin{array}{r}0.000 \\
(.989)\end{array}$ \\
\hline 스포츠 & 229 & 288 & 51 & 123 & 253 & 403 & 141 & 292 & 242 & 354 & 94 & 224 & $\begin{array}{r}4.621 \\
(.032)\end{array}$ & $\begin{array}{c}29.554 \\
(.000)\end{array}$ & $\begin{array}{r}1.551 \\
(.213)\end{array}$ \\
\hline
\end{tabular}

반면 당구장에서의 여가시간 활용도는 국가와 성별이 유의적( $\mathrm{F}=7.939, \mathrm{p}=0.005 ; \mathrm{F}=20.055$, $\mathrm{p}=0.000)$ 이고 상호작용항도 유의적 $(\mathrm{F}=12.951, \mathrm{p}=0.000)$ 인 결과를 보여주고 있다. 당구장에서의 여가시간 활용은 한국 남학생들의 시간활융이 일본보다 매우 높게 나타나고 있옴을 보여주고 있는데, 이용시간은 평균 0.27 시간과 0.11 시간으로 그 차이를 보이고 있다. 여학생의 경우는 0.02 와 0.05 시간으로 일본 여학생이 좀 더 많은 시간을 활용하는 것으로 나타나고 있다. 그러나 국가와 성별에 따른 상호작용이 발생함에 따라 한국의 납학생과 일본의 여학생이 더 많은 시간을 할용하고 있음을 알 수 있다.

\section{5. 결 론}

본 연구에서는 같은 동양문화권에 속하면서도 사회, 문화적 배경이 다론 한국과 일본의 대학생들을 대상으로 라이프스타일 톡성과 여가생활 유형 및 시간활용을 비교하여 살펴보았다. 연구결과는 다음의 몇 가지로 요약될 수 있다.

첫째, 한국과 일본 대학생의 라이프스타일 특성에서는 각 영역별 요인특성에서 많온 차이률 보여주고 있다. 톡히 한국 대학생의 경우 정보추구 부문과 인터넷을 통한 광고 및 네트워크를 통한 가상공간에서의 커뮤니티 활동 둥에서 매우 높은 추구성향을 갖은 반면에 일본 대학생의 경우는 구매 및 쇼핑활동부문에서 유명브랜드를 추구하는 성향이 돋게 나타났다. 라이프스타일 영역별 요인톡성에서는 한국 대학생의 경우 의생활추구분야와 인터넷 정보추구분야 및 인터넷 광고분야에서 일본 대학생들 보다 높은 추구성향올 나타나고 있는 것으로 보여지며, 인터넷을 통한 정보획득과 광고에 대해 많은 관심율 나타내고 있다. 한편 구매 및 쇼평분야에서 일본대학생들은 매우 신중하고 유명브랜트률 선호하며 개성을 추구하는 경향이 높게 나타나고 있옴올 보여주고 있다. 그러나 양국 대학생들의 라이프스타일 요인별 특성에 있어서 신제품구매, 충동구매 등에서는 유의걱인 차이를 나타내고 있지 않았으며, 가치관영역의 핸드폰활용, 가족지향 등의 부문에서도 한국과 일본 대학생듈은 집단간 차이를 보이지 않고 있다. 이는 보편적으로 확산되고 있는 구메성향과 가치관 영역의 일부가 문화견에 따라 차이를 보이지 않고 오히려 공통성울 지니고 있음을 알 수 있다.

둘째, 한국과 일본 신세대 대학생들의 여가시간 활용에도 양국 대학생둘의 차이가 는게 나타나고 있음을 보여주었다. 가장 큰 차이는 한국 대학생의 경우 인터넷 $\mathrm{PC}$ 활용 정도가 높은 반면, 일본의 경우 쇼평예 할애하는 시간이 많은 것으로 나타났다. 그리고 한국의 경우 친구와 만남, 당구장 이용, 오락실, 카폐이용시간, 영화관람 등에 보다 많은 시간을 할애하고 있는 것으로 나타난 반면, 일본의 경우 쇼평을 비롯하여 TV 및 비디오 시청, 스포츠 활동에 보다 많은 여가시간을 할애하고 있다. 
셋째, 성별에 따라 여가생활에 차이를 보여주고 있다. 즉 남학생의 경우 스포츠 활동과 오락실 및 당구장 이용 등에 여가시간올 많이 할애하고 있는 반면에 여학생의 경우는 쇼펑과 카페이용 및 영화관람 등에 더 많은 여가시간을 보내며 친구와 만남, 인터넷 PC활용 및 TV 및 비디오 시청 둥에서는 남학생과 여학생의 여가시간 활용에 대한 유의적인 차이가 나타나지 않고 있다.

넷째, 국적과 인구통계적 요인에 따른 상호작용을 통해 여가시간 활용에 다르게 영향을 미치고 얐는 것으로 나타났다. 즉 인터넷 $\mathrm{PC}$ 활용 및 친구와 만남, 당구장 이용 등에서는 한국 남학생과 일본 여학생들의 활용도가 더 높은 것으로 나타났으며, 카페활용 측면에서는 한국의 여학생과 일본의 남학생이 상대적으로 여가시간을 많이 이용하는 것으로 나타났다.

이러한 연구 결과에 따라 본 연구는 다음과 같은 몇 가지 시사점을 얻었다.

첫째, 서로 다른 문화권의 라이프스타일 특성 및 가치체계에 대한 이해가 국제시장에서의 마케팅 전략수립에 중요한 자로가 될 수 있기 때문에 비교문화적 소비자 행동에 대한 연구가 중요하게 다루어지는 바, 새로운 세대가 추구하는 가치관과 행동성향을 분석함으로써 향후 미래 소비에 어떠한 차이를 나타낼 것인가를 추론하는 것은 매우 중요한 문제라 할 수 있다. 한국과 일본 대학생들을 대상으로 라이프스타일 요인별 특성차이예 근거하여 소비자 행동에 대한 추세를 파악할 수 있는 유용한 지침이 될 수 있을 것이다.

둘째, N세대를 대상으로 마케팅 전략을 수립하고자 한다면 그들의 생할반경 속으로 직접 들어가 보아야 할 것이다. 특히 N세대들의 소비생활과 밀접한 요인은 바로 여가시간 활용인 바, 양국 대학생들의 여가활동 유형을 파악하고, 어떻게 시간활용올 하고 있는지률 파악하는 것은 매우 중요한 지침이 될 것이다. 특히 사회문화적 환겸차이에 따라 여가활동유형올 구분하고 세대별 트랜드를 분석하는 것은 매우 시사적인 작업이라 핟 것이다.

쎗쩨, 한국과 일본 대학생들의 국적과 성별에 따라 상호작용을 통해 여가활동에 다르게 명향을 미치고 있다는 사실을 검증하였다. 이러한 분석방법은 온라인 커뮤니티 운영, 인터닛 광고 및 정보게공 방식 등 연구대상의 활동 유형을 좀더 세분화함으로써 소비자 시장에 좀더 설독력 있게 접근할 수 있는 방안이 될 수 있을 것이다.

본 연구에서는 한국과 일본 대학생의 라이프스타일의 특성과 여가활동을 비교 검증하고 그에 따른 시사점을 추출하였다. 그러나 본 연구는 다음과 같은 몇 가지 한계점을 포함하고 있는 바 이를 바탕으로 앞으로의 연구방향을 제시하고자 한다.

첫째, 본 연구는 표본대상을 한국 대학생 뿐만 아니라 일본 대학생들도 포함시킴으로써 그 연구졀과를 일반화시키려 노력하였으나. 일본의 경우 한정된 지역에서 편의추출하여 자료를 수집한 관계로 본 연구결과률 일반화시키기에는 다소 무리가 있을 수 있다.

둘째, 본 연구에서는 담색적 단계의 연구로서 같은 동양문화권이지만 사회문화적 배경이 다른 양국 대학생 집단간에 라이프스타일 톡성요안을 파악하고, 여가생활 유형과 시간활양 정도에 차이가 있는지의 현상만을 파악하고자 하였으므로 비교문화적 연구로서의 심도있는 성과를 얻었는가 하는 점에서는 의문이다. 따라서 라이프스타일의 톡성상의 차이에 대해 근본원인올 밝히는 문화적 요인(예컨뎨 언어, 종교, 교육, 심미안, 습관-') 을 결부시켜 신세대 소비문화에 미치는 영향을 분석하는 것이 심도있는 연구가 될 것으로 보인다. 


\section{<참고문헌>}

김 훈, 권순일 (1999), “인터넷 사용자의 라이프스타일과 구매의사졀정에 관한 탐색적 연구," 경영학연구, 제28권 제2호, 353-72.

문병준- 손용석(2000), “인터넷을 통한 소비자정보탐색 및 구매행동에 영향을 주는 요인: 개념적 연구," 소비자학연구, 제11권, 제4호, 131-150.

박 철(2000), “인터넷 정보탐색 가치가 인터넷 소팡행동에 미치는 영향에 관한 연구," 마케팅연구, 제 15 권 제 1 호, 143-162.

박 철(2001), “인터넷 정보탐색 가치에 의해 분류한 은라인 소비자 집단별 특성에 간한 연구," 소비자학연구, 제 12 권 제1호, $31-52$.

성영신, 강정석 (2000), “인터넷 쇼핑과 쇼펑몰에 대한 소비자의 지각," 광고학연구, 제 11 권 제2호, 7-34.

송창석, 신종칠(1999), “인터넷상의 상호작용성 제고방안에 관한 연구," 마케팅연구, 제14권 제3호, 69-95.

윤원아- 김기옥(2000), “소비자의 집단주의-개인주의 성향에 관한 척도개빌," 소비자학연구, 제 11 권 제 3 호, 1-14.

이두회, 구지은(2001), "인터넷 쇼핑믈에서의 상호작용성에 관한 연구: 척도개발 맟 료과분석," 마케팅연구 제16권 제2호, 115-140.

이수범(2001), “ 소비자로서의 N세대 성향에 대한 연구," 광고연구 제52호 199-215.

이 철(1995), “비교문화적 소비자행동 연구의 연구모형 및 문헌 분석," 경영학연구, 24권 제2호 85-114.

이 철(1998), “소비자행동 모델의 문화적 한계와 소비자행동연구의 발전방항,” 소비자학연구, 제9권 제1호, 1-15.

전선규, 현용진(1997), “상징적 관여 및 기능적 관여 상황에서 상표태도 형성에 대한 연구," 마케팅연구, 제 12 권 제1호, 77-98.

조형오(1996), “ 한국인의 라이프스타일 유형분류 및 소비행동에 대한 연구," 소비자학뎐구, 제7권 권2호, 223-242.

채서일(1992), “체계분석의 틀여 따른 라이프스타일 연구," 소비자학연구, 제3권 제1호, 46-63.

채정숙(1999), “ 라이프스타일의 비교문화적 연구," 소비자학연구, 재10권 제4호, 79-98. 허윤정 $(2000), \quad \mathbf{r}_{N}$ 세대률 움직이는 마케팅의 귀재들, , 시공사

Aaker, David A., V. Kumar and Goorge S. Day(2001); Marketing Research, 7th, John Wiley \& Sons.

Armstrong, Arthur and John Hagel III (1996), "The Real Value of On-line Communities," Harvard Business Review, May-June, 134-141.

Arnould, E. J. \& Wallendorf, M. (1994), “Market-Oriented Ethnography: Interpretation Building and Market ing St rategy Formulation," Journal of Marketing Research, 'Vol . 31, 484-504.

Baron, Reuben M. and David A. Kenny(1986), " The Moderator-Mediator Variable Dist inction in Social Psychological Research: Conceptual, Strategic, and Statistical 
Considerations, " Journal of Personality and Social Psychology, Vol. 51, No. 6, 1173-1182.

Beatty, Sharon E., Pamela Homer, Lynn R. Kahle, (1988), "Problems with VALS in International Marketing Research: An Example from an Application of the Empirical Mirror Technique," Advances in Consumer Research, 15, 375-380.

Bosshart, David(1997), Die Zukunft des Konsums, ECON Ber lag, 박중대 역(2001), 소비의 미래, 생각의 나무

Carman, J., (1978), "Values and Consumption Patterns: A Closed Loop," Advances in Consumer Research, 5, 404-412.

Churchill, Gilbert A.,(1999), Marketing Research: Methodological Foundations, 7th, The Dryden Press.

Degeratu, Alexandru M., Arvind Rangaswamy, and Jianan Wu (2000), "Consumer Choice Behavior in Online and Traditional Supermarkets: The Effects of Brand Name, Price, and Other Search Attributes," International Journal of Research in Marketing, 17(1), 55-78.

Deighton, John, (1997), "Comment ary on Exploring the Implications of the Internet for Consumer Marketing," Journal of the Academy of Market ing Science, 25(4), 347-351.

Douglas, Susan P. and Christine D. Urban(1997), "Life-Style Analysis to Profile Fomen in International Markets," Journal of Marketing, July, 46-54.

Gurhan-Canli , Zeynep and Durairaj Maheswaran (2000), “ Determinants of Country-of-0rigin Evaluations," Journal of Consumer Research, 27(June), 96-108.

Guth, J. and D. E. Vinson. (1979), "Value Structure and Consumer Behavior," Advances in Consumer Behavior, 6, 335-342.

Hanson, Ward(2000), Principles of Internet Marketing, South-Western College Publ ishing Haubl, Gerald and Valerie Trifts (2000), "Consumer Decision Making in OnJ ine Shopping Environments: The Ef fects of Interactive Decision Aids," Market ing Science, Vol . 19, №. $1,4-21$.

Heimbach, A. E., J. K. Johansson and D. L. MacLachlan(1989), "Product Familiarity, Informat ion Processing and Country-of-Origin Cues," Advances in Consumer Research, $16,460-467$.

Hir schman, El izabeth C. (1980), " Innovat iveness, Novel ty Seeking and Consumer Creat ivity, “ Journal of Consumer Research, 7 (December), 283-295.

Hirshman, Elizabeth C. and Morr is B Holbrook(1982), "Hedonic Consumption: Emerging Concepts, Method and Propositions," Journal of Marketing, 46(Summer), 92-101.

Hof fman, Donna L., and Thomas P. Novak (1996), "Market ing in Hypermedi a computer-Mediated Environments: Conceptual Foundat ion," Journal of Marketing, 60(July), 50-68. Hof stede, Geert (1980), Culture's Consequences: Internat ional Differences in Hork-Related Values, Beverly Hills, CA: Sage Publications.

Hong, Sung-Tai and R. S. Hyer Jr. (1989), "Effects of Country-of-Origin and Product Attribute Information on Product Evaluation: An Information Processing Perspect ive," Journal of Consumer Research, 16(September), 175-187. 
Johansson, Johny K. and Israel D. Nebenzahl (1986), "Mult inat ional Product ion: Effect on Brand Value," Journal of International Business Studies, 17(Fal1), 101-126.

Johansson, Johny K., S. P. Douglas and I. Nonaka (1985), "Assessing the Impact of Country-of -Origin on Product Evaluations: A New Methodological Perspective," Journal of Narketing Research, 22(November), 388-396.

Lastovicka, John L. (1982), "On the Validation of Lifestyle Traits:A Review and Illustration, " Journal of Marketing Research, 19(February), 126-38.

Leclere, France, Bernd Schnitt, and Laurette Dube (1994), "Foreign Branding and Its Ef fects on Product Perceptions and At t itudes," Journal of Market ing Research, 31(May), 263-70

Lisa, Penaloza (2000), "The Commodif icat ion of the American Hest: Marketers' Production of Cultural Meanings at the Trade Show," Journal of Marketing, 64(October), 82-109. Maheswaran, Durairaj (1994), "Country of Origin as a Stereotype: Effects of Consumer Expertise and Attribute Strength on Product Evaluations," Journal of Consumer Research, 21(September), 354-365.

Mayer, Charles(1978), "Mult inational Marketing Research: The Magnifying Glass of Methodological Problems," European Research, 6(March), 77-83.

Nunnally, Jum C. (1978), Psychometric Theory, New York: McGraw-Hill .

Peterson, Robert A. and Alaine J. Jol ibert (1995), "A Meta Analysis of Country-of-Origin Effects," Journal of International Business Studies, 26(4), 883-900.

Rose, Gregory M., (1999) "Consumer Socialization, Parental Style, and Developmental Timetables in the United States and Japan, “ Journal of Marketing, 63(July), 105-119. Singel is, Theodore M., Harry C. Triandis, Dharm P.S. Bhawuk, and Michele J Gel fand (1995), “ Hor izontal and Vertical Dimensions of Individual ism and Collectivism: A Theoret ical and Measurement Refinement," Cross-Cultural Research, 29(3), 241-89.

Steenkamp, Jan-Benedict E. M. and Hans Baumgartner(1998), "Assessing Measurement Invariance in Cross-National Consumer Research," Journal of Consumer Research, 25(June), 78-90.

St eenkamp, Jan-Benedict E. M., Hof stede, F., \& Michel Wedel (1999), " A Cross-National Investigation into the Individual and National Cultural Antecedents of Consumer Innovat iveness," Journal of Marketing, 63(Apri1), 55-69.

Tapscott, Don(1998), Growing up Digital : Net Generation, McGraw-Hill. 허운나. 유영만 역 (1999), N세대의 무서운 아이들, 물푸레

Van den Poel, Dirk and Joseph Leunis, (1999), " Consumer Acceptance of the Internet as a Channel of Distribution," Journal of Business Research, 45, 249-256.

Webster, Frederick E. Jr. (1996), "The Future of Interactive Marketing," Harvard Business Review, (Nev.-Dec.), 156-167.

Zeynep, Gurhan-Canli and Durairaj Maheswaran (2000), "Cultural Variations in Country of Origin Effects," Journal of Market ing Research, 37(August), 309-317. 